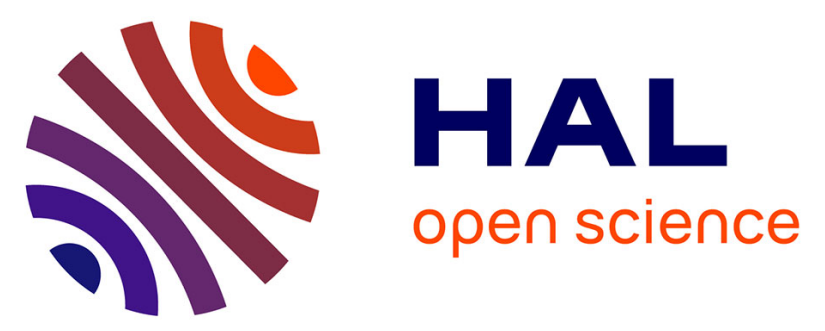

\title{
New Remains of Camelus grattardi (Mammalia, Camelidae) from the Plio-Pleistocene of Ethiopia and the Phylogeny of the Genus
}

Denis Geraads, W. Andrew Barr, Denne Reed, Michel Laurin, Zeresenay Alemseged

\section{To cite this version:}

Denis Geraads, W. Andrew Barr, Denne Reed, Michel Laurin, Zeresenay Alemseged. New Remains of Camelus grattardi (Mammalia, Camelidae) from the Plio-Pleistocene of Ethiopia and the Phylogeny of the Genus. Journal of Mammalian Evolution, In press, 10.1007/s10914-019-09489-2 . hal-02457813

\section{HAL Id: hal-02457813 https://hal.sorbonne-universite.fr/hal-02457813}

Submitted on 28 Jan 2020

HAL is a multi-disciplinary open access archive for the deposit and dissemination of scientific research documents, whether they are published or not. The documents may come from teaching and research institutions in France or abroad, or from public or private research centers.
L'archive ouverte pluridisciplinaire HAL, est destinée au dépôt et à la diffusion de documents scientifiques de niveau recherche, publiés ou non, émanant des établissements d'enseignement et de recherche français ou étrangers, des laboratoires publics ou privés. 
1 New remains of Camelus grattardi (Mammalia, Camelidae) from the Plio-Pleistocene of Ethiopia

2 and the phylogeny of the genus

3

4 By Denis Geraads ${ }^{1,2 *}$, W. Andrew Barr ${ }^{3}$, Denne Reed ${ }^{4}$, Michel Laurin ${ }^{1}$, and Zeresenay Alemseged ${ }^{5}$

${ }^{1}$ CR2P-UMR 7207, CNRS, MNHN, UPMC, Sorbonne Universités, CP 38, 8 rue Buffon, 75231 Paris

7 Cedex 05, France; denis.geraads@mnhn.fr; michel.laurin@mnhn.fr;

$8 \quad{ }^{2}$ Department of Human Evolution, Max Planck Institute for Evolutionary Anthropology, Deutscher

$9 \quad$ Platz 6, 04103 Leipzig, Germany;

$10{ }^{3}$ Center for the Advanced Study of Human Paleobiology, Department of Anthropology, The George

11 Washington University, Washington DC 20052, USA; wabarr@gmail.com;

$12{ }^{4}$ Department of Anthropology, University of Texas at Austin. Austin, TX 78712; USA;

13 reedd@austin.utexas.edu

$14{ }^{5}$ Organismal Biology and Anatomy, University of Chicago, Chicago 60637, USA;

15 alemseged@uchicago.edu;

17 * Corresponding author. ORCID id. 0000-0003-2475-8011

Running head: Plio-Pleistocene Camelus from Ethiopia

\section{Abstract}

The Old World fossil record of the family Camelidae is patchy, but a new partial cranium and some other remains of Camelus grattardi from the Mille-Logya Project area in the Afar, Ethiopia, greatly increase the fossil record of the genus in Africa. These new data - together with analysis of unpublished and recently published material from other sites, and reappraisal of poorly known taxa allow for a comprehensive phylogenetic analysis showing that C. grattardi is the earliest (2.2-2.9 
$27 \mathrm{Ma}$ ) and most basal species of the genus. We also show that the lineages leading to the extant taxa

28 C. dromedarius and C. bactrianus diverged much higher in the tree, suggesting a recent age for this

29 divergence. A late divergence date between the extant species is consistent with the absence of any

30 fossil forms that could be ancestral, or closely related, to any of the extant forms before the late

31 Pleistocene, but stands in contrast to molecular estimates which place the divergence between the

32 dromedary and the Bactrian camel between 8 and 4 million years ago.

33

34 Keywords: Mammalia, Camelidae, phylogeny, Pleistocene, Eastern Africa 


\section{Introduction}

Most of the early evolution of Old World Camelidae, since their immigration from North

America in the late Miocene (Honey et al. 1998; Harris et al. 2010; Rybczynski et al. 2013), seems to have occurred in Eurasia. Late Miocene and early Pliocene forms in Eurasia are usually referred to Paracamelus Schlosser, 1903, a genus that is currently diagnosed primarily by the retention of a lower third premolar, which is lost in the extant genus Camelus Linnaeus, 1758. Paracamelus has a wide distribution from Western Europe (Colombero et al. 2017) to China (Zdansky 1926; Teilhard de Chardin and Trassaert 1937) and through Eastern Europe (Ştefănescu 1895; Khaveson 1954; Kozhamkulova 1986; Logvynenko 2001), but remains very incompletely described. In Africa, it is documented by scrappy remains from the Pliocene of Chad, Tunisia, and Egypt (Harris et al. 2010). Fossil Camelus are also poorly known. The fragmentary remains from the Plio-Pleistocene of OmoTurkana Basin of Kenya and Ethiopia (Howell et al. 1969; Grattard et al. 1976; Harris et al. 2010) have been assigned to C. grattardi Geraads, 2014 (Geraads 2014; Rowan et al. 2018), whose typespecimen is from Member G of the Omo Shungura Formation, dated to 2.2 Ma. Until now, the only fossil camel cranium known in Africa was from the late early Pleistocene of Tighennif, Algeria, which is the type locality of C. thomasi Pomel, 1893 (Martini and Geraads 2018). In 2014, the Mille-Logya Project (MLP) discovered a relatively complete cranium in the upper Pliocene sediments of the Mille-Logya area, Lower Awash Valley, Ethiopia. Its characters match those of the type-specimen of $C$. grattardi, and we assign it to this species. In addition to considerably expanding the hypodigm of C. grattardi, the newly discovered cranium, together with a Veterinary Anatomists (1973). assess the phylogeny of the genus.

All data for this article are included in the following text and in the Supplementary Information. Anatomical terminology is translated from Latin, following the World Association of 
Geological setting

The Mille-Logya Project (MLP), led by one of us (ZA), has conducted research in the Lower

\section{Old World Camelidae}

We compared the MLP fossils to a large sample of extant camels, especially skulls:

C. bactrianus Linnaeus, 1758 (17 skulls; we include here the so-called C. ferus Przewalski, 1878, as there is no evidence that the two species can be distinguished morphologically); C. dromedarius Linnaeus, 1758 (34 skulls); hybrids or unidentified (4 skulls), housed in Muséum National d'Histoire Naturelle, Paris (MNHN), Centre de Conservation et d'Etude des Collections, Lyon (CCEC), and Zoological Institute, Saint Petersburg (ZIN). The distinction between extant species has recently been fully analyzed (Martini et al. 2017). In addition, we have examined the following fossil forms:

1. Camelus sivalensis Falconer and Cautley, 1836, from the upper Siwaliks (Falconer and Cautley 1846; Colbert 1935; Nanda 1978; Gaur et al. 1984), housed in the Natural History Museum, London (NHMUK) and American Museum of Natural History, New York (AMNH); R. Patnaik was kind enough to provide us with photos of the relatively complete cranium A/646 (Sahni and Khan 1988). It was the first fossil camel species to be described, 
and is also the best represented in collections. Its appearance in the upper Siwaliks is dated at 2.6 Ma, or perhaps slightly older (Patnaik 2013). It differs from extant forms in its supraorbital foramina that open wider apart, more complete P3 lingual crescent, broader molars with stronger ribs and styles, more oblique ramus of the mandible, and the shorter ligament scars on the proximal phalanges.

2. The type-cranium of the Middle Pleistocene C. knoblochi Nehring, 1901 (ZIN-8678/8679), a few specimens of the same species from Sjara-Osso-Gol (Boule et al. 1928), stored in MNHN, complemented with photos of other specimens, kindly provided by V. Titov (cranium from Razdorskaya and incomplete skull VSEGEI 7/2932 from Sengiley [Titov 2008]). The species has been reported from a number of middle and upper Pleistocene sites, mostly in Russia, but remains incompletely described. It differs from extant forms mainly in its larger size and a broad infraorbital shelf.

3. C. thomasi Pomel, 1893, from the late early Pleistocene of Tighennif (=Ternifine), housed in MNHN, complemented by photos of the specimens (including the type) kept in the Algiers Museum, kindly provided by Y. Chaïd-Saoudi. The species was first erected for some dental and postcranial remains, but C. Arambourg collected more material from the type locality in 1954-1956, including a complete cranium. This material has been fully described (Martini and Geraads 2018). A few other specimens of $C$. thomasi are from the 'Grotte des Rhinocéros' in Casablanca (Geraads and Bernoussi 2016), but most reports from later sites in North Africa and the Middle East are incorrect (Martini and Geraads 2018). The species is characterized by its large size, pachyostosis (especially marked in the mandible), marked sexual dimorphism, V-shaped choanae, anteriorly located palatine foramina, low placement of orbits, jugular process positioned far from the condyles, an anteriorly positioned P1, P3 with a complete lingual crescent, broad molars with strong styles, an absent or anteriorly located p1, long p4, with a long metaconid, and long limb bones. 
113 4. Early African Camelidae from the early Pliocene of Kossom Bougoudi in Chad (a mandible and two metatarsals housed in Centre National de la Recherche pour le Développement, N'Djamena, Chad (CNRD), described as Paracamelus gigas Schlosser, 1903 [Likius et al. 2003] characterized by large size and the presence of a p3); Pliocene of Ichkeul in Tunisia (a calcaneum housed in MNHN [Arambourg 1979; Harris et al. 2010]), Pliocene of Wadi Natrun in Egypt (a cuboid housed in Senckenberg Museum, Frankfurt [Stromer 1902]), PlioPleistocene of Turkana Basin of Kenya and Ethiopia (various fragmentary specimens housed in Nairobi National Museum [KNM] and NME [Harris et al. 2010; Howell et al. 1969; Harris 1991; Geraads 2014]), late Pleistocene of Algeria (some isolated teeth housed in Université Claude Bernard, Lyon [UCBL; Flamand 1902]).

5. North American camels housed in the AMNH: Megacamelus merriami (Frick, 1921) from Keams Canyon, Arizona, and Edson Quarry, Kansas; Megatylopus gigas (Matthew and Cook, 1909) from the Snake Creek Formation of Nebraska; Megatylopus sp. from the Guymon area of Oklahoma, and Aepycamelus major (Leidy, 1886) from the Mixson beds of Florida. However, because more than one taxon may be present in each of these sites (Harrison 1985), these identifications are not always certain.

Other species are known to us through the literature. The name Camelus alutensis was erected (Ştefănescu 1895) for a small mandible from Romania with a p3, a long symphysis, and a shallow corpus, of which we have seen a cast. The species was later transferred to Paracamelus (Khaveson 1954). The name Camelus kujalnensis Khomenko, 1912, is probably a synonym (Titov 2003), and Paracamelus minor Logvynenko, 2001, could be identical as well. This species has also been tentatively reported from the lowermost Pleistocene of Sarikol Tepe in Turkey (Kostopoulos and Sen 1999), but remains poorly known and poorly defined (Ştefănescu 1910; Topachevskiy 1956; Baigusheva 1971; Rădulescu and Burlacu 1993; Logvynenko 2000; Titov 2003). Taxonomy of these small forms is debatable, but the upper molars from Turkey are unlike those of other Camelidae in their U-shaped valleys, and this small-bodied lineage is probably distinct from other forms. 
140 1903); it is based upon two upper molars, of which one was selected (Van der Made and Morales

141 1999) as lectotype; unfortunately, this tooth is no longer part of Schlosser's collection in München

142 (G. Rössner pers. comm.). From the figure (Schlosser 1903: pl. 9, figs. 14 and 26), this molar differs 143 from those of Camelus in that both the mesostyle and the buccal pillar of the paracone are distinctly 144 broader, especially near the base, the central anterior valley is wider, and the labial crescents have a 145 less regular thickness. Taken together, these features give the tooth a distinct overall pattern, even 146 suggesting that it might not be camelid at all, but much less scrappy camelid material from Loc. 102 in Henan, China, was assigned to P. gigas by Zdansky (1926) so that his material became the reference for this taxon, although species identification was merely based upon size; for the sake of nomenclatural stability, we shall continue using Schlosser's name. Additional material comes from Shansi (Teilhard de Chardin and Trassaert 1937). The species was identified (Teilhard de Chardin and Piveteau 1930) from the early Pleistocene of Nihowan on the basis of absence of a medioplantar astragalar facet on the calcaneus, but this facet may also be lacking in $C$. bactrianus and $C$. thomasi so this identification is unsupported. The name Paracamelus alexejevi Khaveson, 1950, was erected for the abundant material of the Odessa catacombs; later its author (Khaveson 1954) revised Old World camels and provided the first diagnosis of Paracamelus, as then understood. It included: 1) presence of p3 and dp2; 2) strong ribs and styles on molars; 3) long P3; 4) paraconid distinct from parastylid on p4; 5) cranium longer and narrower than in Camelus, and 6) some differences in mandibular proportions, especially a longer lower jaw. In fact, the morphology that he described and illustrated for the $\mathrm{p} 4$ of $P$. alexejevi may be present in C. dromedarius as well, although he correctly observed that this species differs

161 from C. bactrianus in that the central valley is never closed lingually. The long P3 and presence of p3 are clear, and the long mandible is probably also a valid difference, but other differences in cranial and mandibular proportions remain to be fully documented because the most complete illustrated skull (Khaveson 1954: pls 2 and 10) is largely reconstructed in plaster; in a more reliable 
cranium (Khaveson 1954: fig. 1), the position of the orbit is similar to that of Camelus. The species P. alexejevi was defined (Khaveson 1954) by its slender limbs and by the small difference in the mean lengths of the metacarpal and metatarsal ( $3 \mathrm{~mm})$, but this value is well within the range of extant forms (Martini et al. 2017, and our observations). We have not seen the Ukrainian and Russian material of Paracamelus, but some data and photos were provided by T. Krakhmalnaya and N. Podoplelova, and a cast of the type specimen of $P$. alutensis was examined in UCBL.

In addition, several species of poorly constrained age were erected on scrappy material. These are Procamelus khersonensis Pavlow, 1904, based upon a juvenile cranium, Camelus bessarabiensis Khomenko, 1912 (Simionescu 1930, 1932), and Camelus praebactrianus Orlov, 1927 (Orlov 1929), based upon some postcranial bones.

In the purported Gigantocamelus sp. from Ukraine (Svistun 1971), the length of the lower molar series looks overestimated, and the distal metapodial is really large only if it is a metatarsal, as assumed by him, but even smaller than in C. knoblochi if it is in fact a metacarpal. In 'Gigantocamelus longipes’ from Kazakhstan (Aubekerova 1974) the measurements of a metacarpal match those of a metatarsal of P. gigas (Teilhard de Chardin and Trassaert 1937), and should probably be attributed to this species.

Paracamelus aguirrei Morales in Van der Made and Morales, 1999 (this species was first described in an unpublished thesis [Morales 1984]; it seems that the name was validated only in 1999) from Venta del Moro (Morales et al. 1980; Morales 1984; Pickford et al. 1995; Van der Made and Morales 1999) and Librilla (Alberdi et al. 1981) is the earliest camel of Europe, of latest Miocene age. It is poorly known but the upper molars are distinctly brachydont, broad, and have strong styles. A juvenile lower dentition from the upper Miocene of Çoban Pinar, Turkey, was assigned to Paracamelus cf. $P$. aguirrei (Van de Made et al. 2002); its provenance remains uncertain (Sen 2010; Van der Made and Morales 2013) but the long, high-crowned m1 matches extant forms. The few postcranials from the middle (?) Pliocene of Garaet Ichkeul in Tunisia (Arambourg 1979) were also assigned to P. aguirrei (Van der Made and Morales 1999), with poor support. The same 
species was reported (Titov and Logvynenko 2006) from the northern shore of the Black Sea in sites assumed to be earlier in age than Venta del Moro and Çoban Pinar.

Probably the most interesting sites for the history of Old World camels are those recently excavated in Syria by the University of Basel. No details have been published yet, but various sites ranging from the early to the late Pleistocene have provided as many as three different species, two of them being giant forms (Martini et al. 2015). It is likely that the very incomplete remains from Latamne (Hooijer 1961) and Ubeidiyeh (Haas 1966; Geraads 1986) will have to be referred to one or more of them.

\section{Description and comparisons}

\section{Mille-Logya material:}

The specimen NME-MLP-1346 consists of several parts, including some teeth and fragments recovered by screening, but due to their close physical proximity and identical preservation there is no doubt that they all belong to the same individual (Figs. 1-2; Supplementary Information 1). The largest piece is the posterior part of a cranium with parts of the orbits; in addition, there are the left and right maxillae with most of the teeth, parts of the left and right zygomatic bones, and a piece of the snout consisting of partial palate, vertical part of the maxilla, and partial premaxilla. The cranium is dorsoventrally crushed but distortion affected mostly the braincase itself, while the occiput looks virtually undistorted; in addition, the left squamosal is rotated counterclockwise by about $70^{\circ}$, so that the zygomatic arch is now directed almost ventrally. Dental dimensions suggest that this specimen was a young adult female; the great width of the molars compared to their length, the narrow fourth upper premolar, and the strong labial styles match the type specimen of C. grattardi.

The only measurement that can be taken accurately, width across occipital condyles, is within the range of extant Camelus, although close to its upper limit. Postorbital width is above the extant range, but may have slightly increased because of deformation. Thus, on the whole it is comparable in size to C. bactrianus, C. thomasi, and C. sivalensis, but smaller than C. knoblochi. 
The snout fragment comprises parts of the palate, the ascending part of the maxilla, and the

218 premaxilla. The last is distinctly narrower than in C. thomasi (Martini and Geraads 2018); it certainly

219 did not widen posteriorly, in contrast to that of C. sivalensis (AMNH-FM19832) and of most extant

220 specimens, and it is very unlikely that it reached the nasals. The erupting permanent canine is

221 preserved within the bone; its tip just reaches the palatal level; the relatively small size of this tooth,

222 reflected in the lack of lateral inflation of the maxilla, suggests that the cranium is from a female

223 individual. In front of the canine, the alveolus of the missing (shed ?) deciduous canine is visible.

224 Not far behind, about one half of a large P1 alveolus is preserved; it is usually located more

225 posteriorly in C. bactrianus (Martini et al. 2017). This (missing) tooth was not much smaller than the

226 canine, confirming the sex of the animal. The P1 may be absent in extant forms and in C. knoblochi;

227 it is absent in the one known specimen of $P$. gigas, but given the documented variation in Camelus,

228 this is insufficient to bar this species from the ancestry of Camelus (contra Zdansky 1926). At the

229 level of the canine, the maxilla reaches the sagittal plane whereas in extant forms the posterior

230 processes of the premaxillae intervene; this suggests that the incisive fissures were located more

231 rostrally in the fossil form. In front of the cheek-teeth, there is no evidence of a crest bordering the

232 palate, nor of a sharp narrowing of the latter anterior to P3. The missing palatine bone reached the

233 limit M1/M2, a position that is within the range of variation of the extant forms. There is a single

234 pair of palatine foramina at the level of the first lobe of M1, a position more common in

235 C. bactrianus than in C. dromedarius; they are even more posterior in C. knoblochi, but in

236 C. sivalensis and C. thomasi, the main pair of foramina opens at the level of $\mathrm{P} 4$, as in most

237 C. dromedarius. The choanae are not preserved, but the lateral palatine notches do not reach beyond

238 the posterior border of M3.

239 The zygomatic bone is almost intact on the left but only a piece of the right bone is preserved;

240 they can be satisfactorily oriented. Posteriorly, the deep groove for the squamosal reaches farther

241 anteriorly, by at least $1 \mathrm{~cm}$, than the level of the posterior border of the orbit. In contrast, in all extant

242 specimens, in C. knoblochi, C. thomasi, and P. gigas, the most rostral point of the squamosal remains 
distinctly more caudal. The only species showing a squamosal reaching the orbital level is P. alexejevi (Khaveson 1954: fig. 1), and the same condition is also observed in Megacamelus merriami. Under the orbit, the zygomatic bone forms a flat shelf, about $2 \mathrm{~cm}$ deep, facing laterally more than ventrally. It is limited by a clear ventral edge and proceeds posteriorly into the lateral face of the zygomatic arch, whose ventral edge is concave at this level. The maxilla shows that this shelf extends forwards as far as the anterior orbital border and forms a flange over a well-marked longitudinal groove. This shelf is weak in the dromedary, but moderate or variable in other Camelus, except in the three specimens of $C$. knoblochi, where it is broad. The small infraorbital foramen is located above P4, as in other Old World camels.

The braincase is rounded and clearly limited anteriorly at the level of the postorbital constriction, but also posteriorly where it is distinctly pinched before the nuchal crest; it may be that deformation increased its greatest width which is located at mid-height. The strong, prominent sagittal crest extends from the nuchal crest to the middle of the braincase, where it gently diverges into the temporal lines. There is a single supraorbital foramen on either side, and they are located far apart (66 mm between their centers). In extant Camelus, and in C. knoblochi, there are usually multiple foramina, and they are always closer to the midline (Supplementary Information 2-3). The condition in C. sivalensis is observable in NHMUK-PV-OR36664: it is similar to that of NME-MLP1346, with a distance of $64 \mathrm{~mm}$ between the centers; the cranium A/646 (Sahni and Khan 1988) has multiple foramina but they are also located rather far apart (photos provided by R. Patnaik). The mandibular fossa is virtually flat. It is bordered posterolaterally by a postglenoid process, but there is no lateral tubercle on the ventral border of the zygomatic arch. This paraglenoid tubercle is always present in all other species of Camelus.

There is no evidence of transverse deformation of the auditory region, cranial base, and occipital, at least on the right side and, save for the left squamosal that is rotated, this area is symmetrical, and distortion is probably minimal. The braincase is somewhat crushed dorsoventrally and it may be that some transverse compressing occurred behind it. The imperfectly preserved right 
auditory region displays a relatively large tympanic bulla, with inflation anteromedially of the tympanohyal vagina. The basioccipital is strongly pinched in front of the occipital condyles, forming large, deep depressions between the midline and the bullae, as in C. sivalensis (NHMUK-PVOR39597, AMNH-FM19785). Although this is hard to quantify, the basicranium looks short; in contrast, the C. sivalensis cranium AMNH-FM19785 looks long, but its central part is incorrectly reconstructed in plaster. The plane of the incomplete jugular process is inclined at more than $45^{\circ}$ to the sagittal plane, thus slightly more transversally than in extant forms, C. knoblochi, and C. sivalensis (NHMUK-PV-OR39597, A/646), and distinctly more so than in C. thomasi, in which it is located far away from the occipital condyle. The hypoglossar foramen is not visible.

The central part of the occipital surface, above the foramen magnum, forms a broad pillar that is much more prominent caudally than the lateral parts of the occipital, above the condyles.

However, the dorsal part of this raised area is depressed on either side of a weak occipital crest, below the central part of the nuchal crest. Laterally, the nuchal crest is perhaps slightly damaged, but the outline of the occipital was clearly bell-shaped, even accounting for slight transverse crushing. In extant forms, the shape of the occipital mainly depends on the development and degree of flaring of the nuchal crest, but it never looks so narrow; C. sivalensis (NHMUK-PV-OR39597; AMNHFM19785; A/646) and C. thomasi (Martini and Geraads 2018) also have broad occipitals.

All cheek-teeth are preserved, either on the right or left sides (Fig. 1; Table 1; Supplementary Information 1). The P3 consists mostly of a buccal crescent, with parastyle, metastyle, and a rounded pillar located slightly mesially, about as prominent as the styles. A crest descends from the distal part of the buccal wall towards the lingual side, and curves mesially to meet a low ridge best indicated mesiolingually and distally, at the base of the main buccal wall. Although this ridge is clearly homologous with a lingual crescent, it clearly remains below occlusal level until late wear. There is much variation in size and morphology of the P3 of Old World camels. In extant forms the lingual crescent is rarely almost complete; it is usually mostly restricted to its distal part, and may be as weak as in NME-MLP-1346. Camelus knoblochi also has an incomplete lingual crescent, like 
P. gigas (Zdansky 1926). In C. sivalensis, instead, all three P3s (NHMUK-PV-M100160, NHMUKPV-XX40570, AMNH-FM19832) have a fully-formed lingual crescent, and this also seems to be true of other specimens (Gaur et al. 1984; cranium A/646). The single known P3 of C. thomasi (Martini and Geraads 2018) also has a complete lingual crescent.

The P4 is still unworn, while M3 is slightly affected by wear. The reverse occurs usually, but not always, in extant forms; the sequence of tooth eruption further differs from that of the extant forms in that all molars are touched by wear before the full eruption of the canine. The buccal crescent of P4 is very similar to that of P3 but, in addition, there is a fully formed lingual crescent that sends a strong distal spur into the central valley; such a spur is smaller or absent in extant Camelus, C. thomasi, and C. sivalensis. Still, this tooth remains long and narrow. The molars have a faint metacone rib and a more distinct paracone rib. The parastyle and mesostyle are strong, and distinctly overlap the preceding lobe (paracone, or metacone of the preceding tooth); in these strong styles, NME-MLP-1346 resembles more C. thomasi and C. sivalensis than the average condition of the extant species. Although measurements must be used with caution because length of the molars decreases dramatically with wear, the upper molars are broad relative to their length. This is also true of fossil Camelus in general (Supplementary Information 2).

All teeth are rather brachydont, although they possess some cementum cover. Although height cannot be precisely measured on the molars, the height of M3 was certainly less than its length. The unworn P3 is only slightly taller than long, and P4 is only moderately hypsodont. This contrasts with extant Camelus, and with the fossil C. sivalensis and C. thomasi (Table 2). In labial view (Fig. 1F), cusp shape is high and sharp on the little-worn M3s, but more rounded on the M1s (and on isolated, more worn teeth), suggesting a basically browsing behavior. NME-MLP-2680 best matches the morphology of a lower canine, and is probably from a female individual, and probably of the same individual as NME-MLP-2665 and NME-MLP-2684, 
two upper molars; the metacone wall is flat, but the mesostyle and paracone rib are better indicated than in extant forms (Fig. 3A-B), and these teeth are broad relative to their length.

Most measurements of the distal tibia NME-MLP-2584 (Fig. 3C) are above the maximum recorded ones for extant Camelus (Martini et al. 2017), but the proportions are similar. As in C. sivalensis, the medial malleolus is weaker than in extant forms, C. thomasi, and C. knoblochi, but this feature is variable in North American forms. As for the cranial remains, the large size of the tibia suggests an animal somewhat taller than the living forms, but probably not heavier than well-fed domestic animals, which can reach about $1000 \mathrm{~kg}$.

NME-MLP-1189 is a complete astragalus (Fig. 3D), and NME-MLP-1144 a distal half; the extant forms display a great intraspecific variation but some differences can be observed (Steiger 1990; Martini et al. 2017). NME-MLP-1189 is not broader than other Camelus, but taller (Supplementary Information 2-3). The part of distal trochlea that corresponds to the cuboid is narrower than in all C. dromedarius, and more like C. bactrianus, C. sivalensis, and C. thomasi, but this cuboid facet is broader in NME-MLP-1144, as in C. dromedarius. In lateral view, the tibial facet is strongly convex and its proximal end extends far towards the plantar side (see also Steiger 1990: fig. 52) as being a characteristic of $C$. dromedarius compared to $C$. bactrianus, but also found in C. sivalensis, whereas $C$. thomasi resembles more C. bactrianus. The lateral calcaneal facet is not contiguous with the plantar one, in contrast to the usual condition in extant forms. Obviously, fossil forms display a mixture of the characters of both extant species, and it would be misleading to search for the extant types of astragali among them, but NME-MLP-1189 is unlike all other species in its slenderness.

\section{Additional material of Camelus grattardi from Omo:}

The type specimen of $C$. grattardi is from Member G of the Shungura Formation at Omo, Ethiopia (Geraads 2014); these deposits are somewhat younger than all localities in the MLP area. It clearly differs from both extant species in its narrow P4 and broad molars; these characters match those observed in the MLP camel and, given the geographic and chronological proximity, we 
confidently assign the MLP camel to C. grattardi. Thus, features observable on the material from the MLP area can be complemented by those of other specimens of C. grattardi. Only some of those from the Omo Shungura Formation have been published (Howell et al. 1969; Grattard et al. 1976; Geraads 2014; Rowan et al. 2018), but we have now been able to examine all specimens from the early expeditions; they are briefly described below.

NME-L480-7 from lower Member G is a piece of mandible with heavily cracked, incomplete m1-m3 (Fig. 4A). At ca. 2.2 Ma, it is the earliest specimen demonstrating the absence of p3. All three molars display an incipient goat fold; although they are worn and damaged, they are relatively high-crowned. The unnumbered lower molar collected by Arambourg in 1933 (Fig. 4C), probably from a similar level, also bears a weak goat fold. This is also true of the $\mathrm{m} 3$ in the mandible fragment NME-Omo28-67-494 (upper Member B; Fig. 4D), which has a narrow corpus (thickness at m1-m2 $=33 \mathrm{~mm}$ ) that is even less thick than that of $C$. bactrianus, but this specimen is older than those formally identifiable as C. grattardi.

The color and weathering of the proximal humerus NME-L1-68-36 from Omo Shungura Upper Member B differ from those of the Camelus distal humerus NME-L1-68-76, so that there is no evidence that they are from the same individual, in contrast to what was hypothesized (Geraads 2014). Its identification is not straightforward; it was compared with modern Camelus (Grattard et al. 1976) but the tuberculum minus is much lower, the tuberculum majus higher, and the medial part of the intertubercular sulcus (bicipital groove) narrower and deeper; it differs in the same features from North American giant camels, and we conclude that NME-L1-68-36 probably belongs to Giraffa Brisson, 1772, instead, although not a perfect match with this genus. The distal humerus NME-L168-76 is definitely camelid but, at ca. $3 \mathrm{Ma}$, it is older than other specimens of C. grattardi, and it now seems safer not to include it in the hypodigm of the species.

The proximal phalanges NME-Omo 28-67-577 (Upper Member B; Fig. 4E) and NME-Omo 119-68-14 (Member D; Fig. 4B) were, probably correctly, assigned to the anterior and posterior limbs, respectively (Grattard et al. 1976). Both phalanges have relatively shorter distal condyles, and 
shorter ligament insertions on the palmar/plantar face than in extant Camelus. However, whereas in extant forms the posterior proximal phalanx is basically a smaller version of the anterior one, these two Omo phalanges differ little in length, but strongly so in their morphology, NME-Omo 119-68-14 being almost as long as NME-Omo 28-67-577 but distinctly more slender. The former can probably be identified as C. grattardi; it differs from extant Camelus in its very deep (antero-posteriorly) proximal articulation. The latter can hardly be assigned to the same species and, like other specimens from Shungura Upper Member B, we prefer to leave it as ?Camelus sp.

\section{Systematic paleontology}

CAMELIDAE Gray, 1821

CAMELUS Linnaeus, 1758

Type species—Camelus bactrianus Linnaeus, 1758.

CAMELUS GRATTARDI Geraads, 2014

Holotype-NME-Omo75S-70-956, maxilla fragment with P4-M3; from lower Member G (G4 to

G13), Shungura Formation, lower Omo valley, Ethiopia; ca. 2.2 Ma.; housed in NME.

Referred material from Mille-Logya-NME-MLP-1346, incomplete cranium including the braincase, parts of the orbits, palate, maxilla, and most of the tooth-rows, found in 2014 by Moges Mekonnen (geographic coordinates $11.56437^{\circ}$ N, 40.83878 E); NME-MLP-2680, lower canine; NME-MLP2665, upper molar; NME-MLP-2684, incomplete upper molar, probably M3; NME-MLP-1189, astragalus; NME-MLP-1144, incomplete astragalus; NME-MLP-2584, distal tibia. All this material is from the Seraitu unit, ca. 2.9 - 2.5 Ma.

Diagnosis-A large member of Camelus, with supraorbital foramina located wide apart, squamosal reaching the orbital level, narrow occiput, mesial border of the mandibular ramus strongly inclined backwards, upper molars only slightly longer than broad, with prominent styles, P4 much narrower than M1, proximal phalanges with short posterior scars, posterior proximal phalanx with a deep proximal articulation. Differs from species of Paracamelus in the deeper infraorbital shelf, loss of 
p3, smaller P3, weaker molar ribs, and shorter scars on the proximal phalanges. Differs from all other species of Camelus in: tall occiput, squamosal reaching the orbital level, absence of paraglenoid 400 tubercle, deeper mandibular corpus, narrow P4, less hypsodont teeth, and tall astragalus. Differs 401 additionally: from extant C. bactrianus and C. dromedarius in its late canine eruption, deep infraorbital shelf, supraorbital foraminae wide apart, more oblique anterior border of mandibular ramus, broader molars, stronger, thicker styles in the upper teeth, more cylindrical and more transverse distal humeral articulation, and proximal phalanges with shorter ligament scars; from the 405 Pleistocene North-African C. thomasi in its deep infraorbital shelf, supraorbital foraminae wide apart, much less complete P3 lingual crescent, lack of pachyostosis, longer lateral lip and broader cuboid trochlea on the astragalus, and shorter scars on the proximal phalanges; from $C$. sivalensis from the Siwaliks in the deeper infraorbital shelf, less complete P3 lingual crescent, and weaker molar ribs.

\section{Parsimony analysis}

Old World fossil camels have to date been mostly represented by incomplete remains. Most previous studies assumed, a priori, that they were more closely related to one or the other of the extant forms than to other stem camelids. The new finds from the MLP area, in conjunction with the recent reappraisal of the distinguishing features between the extant taxa (Martini et al. 2017), the study of the only other significant African sample (Martini and Geraads 2018), and the revision of incompletely described samples allow for a comprehensive analysis of their relationships

418 (Supplementary Information 2 and 4). A total of 22 characters, all ordered (Supplementary 419 Information 2-4), were used in a parsimony analysis, using TNT (Goloboff et al. 2003; Goloboff and 420 Catalano 2016) and PAUP*4 (Swofford 2003). To the Camelus species mentioned above, we added 421 P. gigas, P. alexejevi, and P. alutensis. Because Old World camels immigrated from North America, 422 the outgroup taxon must be sought there. We chose Megacamelus merriami, which is the best423 documented close relative of Old World camels. 
Our parsimony analysis yields three equally parsimonious trees that differ only in the

branching pattern within Paracamelus (the resolution of this trichotomy with the highest bootstrap frequency is shown in Fig. 5). The trees indicate that Camelus grattardi is the most basal branch of the Camelus clade. It is followed by the southern Asian C. sivalensis, and the North Africa C. thomasi; this succession is consistent with the ages of these species, $C$. sivalensis being of early Pleistocene age, C. thomasi of late early to early middle Pleistocene age. The newly recovered MLP material provides the oldest evidence (at $2.9-2.5 \mathrm{Ma}$ ) of one of the most diagnostic characters for the species, a small P3. By contrast, on the mandible KNM-ER 2608 from the Koobi Fora Formation dated to ca. 3.5 Ma (Harris 1991), the absence of p3, functionally correlated with a small P3, cannot be definitely ascertained, and the predental portion is extremely long, suggesting that KNM-ER 2608 potentially documents instead one the latest occurrences of Paracamelus in Africa. Camelus grattardi thus suggests that the genus Camelus arose in eastern Africa ca. 3 Ma, when Paracamelus went extinct.

The precise dating of $C$. grattardi has important consequences on the chronology of the origin and diversification of the genus Camelus. The results of the parsimony analysis are consistent with the chronology of the fossil record. Our results are only moderately robust, but the most robust clade is precisely that which includes only crown camelids, with a bootstrap of $70 \%$ and a decay index (Bremer 1988) of 2. Our estimate of the minimal age for the crown group, for the divergence between $C$. dromedarius and C. bactrianus, is about 0.6 to $0.8 \mathrm{Ma}$ and matches the age of the oldest known remains of $C$. knoblochi (Titov 2008), No fossil form that could be part of this crown clade is known before the middle Pleistocene, so there is no fossil evidence that this crown clade predates the middle Pleistocene. In fact, even this age could be too old, as it rests upon the poorly known C. knoblochi (Titov 2008); should detailed study of this species show that it is in fact no more closely related to $C$. dromedarius than to $C$. bactrianus, a possibility raised by the low Bremer index (1) and low bootstrap frequency (50\%) of the node uniting C. knoblochi to C. dromedarius, the divergence between the extant taxa could even be younger. The position of $C$. knoblochi in the crown 
of Camelus dispels doubts that the topology of crown Camelus is influenced by domestication because if the latter had caused considerable phenotypic convergence between $C$. dromedarius and C. bactrianus, the long extinct (hence, undomesticated) C. knoblochi should logically be excluded from the crown.

\section{Conclusion}

Our estimate of the minimal divergence date between the lineages leading to the extant species, certainly not earlier than the middle Pleistocene and perhaps late in this age, is much more recent than the estimates provided by molecular analyses: ca. 4.4 Ma using the whole genome (Wu et al. 2014), and ca. 4.1 Ma by comparison with the genome of the late middle Pleistocene American Camelops Leidy, 1854 (Heintzmann et al. 2015). On the basis of the mtDNA sequence, it was even suggested (Cui et al. 2007) that this divergence occurred before the Camelidae immigrated into the Old World, ca. 8 Ma.

Our analysis based on morphological and stratigraphic data suggests Camelus dates from the late Pliocene, and the divergence of the extant lineages is much younger than estimated by molecular analyses. Of course, part of the discrepancy may reflect the fact that paleontological data directly provide only minimal divergence age estimates, whereas molecular ages attempt to provide unbiased estimates of divergence dates, but this factor alone is unlikely to account for the five-fold difference or more between our paleontological estimate and molecular estimates. A number of increasingly sophisticated and realistic methods have been developed to get unbiased estimates and confidence intervals from paleontological data (e.g., Strauss and Sadler 1989; Marshall 2008), but this requires extensive dataset compilation and the use of methods that are beyond the scope of our study.

Nevertheless, our estimate is also supported by the fertility of $C$. dromedarius $\times C$. bactrianus, whose hybrids are fertile up to the F4 when backcrossed with either species (Faye and Konuspayeva 2012). Among other artiodactyls, fertile hybrids are unknown between species whose divergence is earlier than the Pleistocene (Gray 1972). 
conditions (Wu et al. 2014). By contrast, stem Camelus seem to be associated with a variety of fossil assemblages, and might have been able to thrive in diverse environments, but none of them is suggestive of subdesertic conditions. Pending detailed analysis of the ecology of fossil Old World camels, the adaptation to desert conditions may be another, recently acquired synapomorphy of extant Camelus.

\section{Acknowledgments}

We thank the Authority for Research and Conservation of Cultural Heritage and the Afar

Regional State for permission to conduct field work in the Mille-Logya area. We also express our gratitude to the people of the Mille and Logya towns and environs for permission and logistical support. We are grateful to C. Argot and J. Lesur (MNHN), G. Baryshnikov (ZIN), D. Berthet (CCEC), P. Brewer (NHMUK), J. Galkin (AMNH), T. Getachew and Y. Assefa (NME), M. Muungu (KNM), and E. Robert (UCBL) for access to collections, to J.-P. Brugal, Y. Chaïd-Saoudi, B. Kear, photos and other data on fossil collections, to P. Loubry for the photos of Fig. 4, to V. Codrea, P. Martini, and N. Spassov for their help with foreign literature, and to S. Colombero and J. Rowan, whose comments significantly improved the manuscript. Funding to conduct field work was provided by Margaret and Will Hearst.

\section{Supplementary Information:}

497 Supplementary Information 1. 3D reconstruction of NME-MLP-1346 (made with Agisoft 498 Photoscan). [File Geraads\&al_Camelus_SupInfo1.pdf]

499 Supplementary Information 2. Description of the characters used in the parsimony analysis; 
501 Supplementary Information 3. Raw measurements used in Supplementary Information 1 [File

502 Geraads\&al_Camelus_SupInfo3.xlsx]

503 Supplementary Information 4. Matrix used in the parsimony analysis, in Nexus format. [File 504 Geraads\&al_Camelus_SupInfo4.nex]

\section{References}

507 Alberdi MT, Morales J, Moya S, Sanchiz B (1981) Macrovertebrados (Reptilia y Mammalia) del 508 yacimiento finimioceno de Librilla (Murcia). Estud geol 37: 307-312

Alemseged Z, Barr WA, Bobe R, Geraads D, McPherron S, Reed D, Wynn J (2016) A new late Pliocene Fauna from the Mille-Logya Project (MLP) Area, Afar Regional State, Ethiopia. $24^{\text {th }}$ Annual Meeting of the Paleoanthropology Society, Atlanta, GA

Arambourg C (1979) Vertébrés villafranchiens d'Afrique du Nord (artiodactyles, carnivores, primates, reptiles, oiseaux). Fondation Singer-Polignac, Paris, 141 pp

Aubekerova PA (1974) New giant camel from Pliocene deposits of Tekess depression. Materials for the history of fauna and flora of Kakakhstan, Akad Nauk SSR Kazhakstan Inst Zool 6: 74-82 [in Russian]

Baigusheva VS (1971) Fossil theriofauna of the Liventzovka sand-pit. Tr Zool Inst Akad Nauk 49:

$$
\text { 5-29 [in Russian] }
$$

Bibi F, Rowan J, Reed K (2017). Late Pliocene Bovidae from Ledi-Geraru (Lower Awash Valley, Ethiopia) and their implications for Afar paleoecology. J Vertebr Paleontol doi:10.1080/02724634.2017.1337639

Boule M, Breuil H, Licent E, Teilhard de Chardin P (1928) Le Paléolithique de la Chine. Arch Inst paléontol hum 4: 1-138 Evolution 42: 795-803 
528 Colombero S, Bonelli E, Pavia M, Repetto G, Carnevale G (2017) Paracamelus (Mammalia, Camelidae) remains from the late Messinian of Italy: insights into the last camels of western Europe. Hist Biol 29: 509-518

Cui P, Ji R, Ding F, Qi D, Gao H, Meng H, Yu J, Hu S, Zhang H (2007) A complete mitochondrial genome sequence of the wild two-humped camel (Camelus bactrianus ferus): an evolutionary history of Camelidae. BMC genomics 8(241), doi:10.1186/1471-2164-8-241

Falconer H, Cautley PT (1836) Note on the fossil camel of the Siwalik Hills. Asiatic Res 19: 115134

Falconer H, Cautley PT (1846) Fauna Antiqua Sivalensis, Being the Fossil Zoology of the Sewalik Hills, in the North of India. Smith, Elder and Co, London, 590 pp

Faye B, Konuspayeva G (2012) The encounter between bactrian and dromedary camels in Central Asia. In: Knoll EV, Burger P (eds) Camels in Asia and North Africa: Interdisciplinary Perspectives on Their Past and Present Significance. Österreichische Akademie der Wissenschaften, Wien, pp 27-33

Flamand GBM (1902) Sur l'utilisation, comme instruments néolithiques, de coquilles fossiles à taille intentionnelle (littoral nord-africain). C R Assoc fr Av Sci 30: 729-734

Frick C (1921) Extinct vertebrate faunas of the badlands of Bautista creek and San Timoteo cañon, Southern California. Univ Calif Publ Bull Dept Geol 12: 277-424

Gaur R, Raghavan P, Chopra SRK (1984) On the remains of Camelus sivalensis (Artiodactyla, Camelidae) from Pinjor Formation of Upper Sivaliks. Ind J Earth Sci 11: 158-165

Geraads D (2014) Camelus grattardi nov. sp., a new camel from the Shungura Formation, Omo valley, Ethiopia, and the relationships of African fossil Camelidae (Mammalia). J Vertebr Paleontol 34: 1481-1485

551 Geraads D (1986) Ruminants pléistocènes d'Oubeidiyeh. Mém Trav Cent Rech fr Jérus 5: 143-181 552 Geraads D, Bernoussi R (2016) Hippopotamidae, Suidae et Camelidae. In: Raynal J-P, Mohib A 
(eds) Préhistoire de Casablanca. 1. La Grotte des Rhinocéros (Fouilles 1991 et 1996). Villes et Sites Archéologiques du Maroc, 6, Ministère de la Culture, INSAP, Rabat, pp 133-134

Goloboff PA, Catalano SA (2016) TNT version 1.5, including a full implementation of phylogenetic morphometrics. Cladistics 32: 221-238

Goloboff PA, Farris J, Nixon K (2003) TNT, Tree analysis using New Technology [software]. www.lillo.org.ar/phylogeny/tnt

Grattard J-L, Howell FC, Coppens Y (1976) Remains of Camelus from the Shungura Formation, lower Omo valley. In: Coppens Y, Howell FC, Isaac GLl, Leakey REF (eds) Earliest Man and Environments in the Lake Rudolf Basin. University of Chicago Press, Chicago, pp 268274

Gray AP (1972) Mammalian hybrids: a check-list with bibliography. Commonwealth Agricultural Bureaux, Slough, $262 \mathrm{pp}$

Gray JE (1821) On the natural arrangment of vertebrose animals. London Medical Repository 15: 296-310.

Haas G (1966) On the Vertebrate Fauna of the Lower Pleistocene Site 'Ubeidiya. Israel Academy of Sciences and Humanities, Jerusalem, 68 pp

Harris JM (1991) Camelidae. In: Harris JM (ed) Koobi Fora Research Project. Volume 3: The Fossil Ungulates: Geology, Fossil Artiodactyls and Palaeoenvironments. Clarendon Press, Oxford, pp 86-91

Harris JM, Geraads D, Solounias N (2010) Camelidae. In: Werdelin L, Sanders WJ (eds.) Cenozoic Mammals of Africa. University of California Press, Berkeley, pp 815-820

Harrison JA (1985) Giant camels from the Cenozoic of North America. Smithson Contrib Paleobiol 57: $1-29$

Heintzman PD, Zazula GD, Cahill JA, Reyes AV, MacPhee RDE, Shapiro B (2015) Genomic data from extinct North American Camelops revise camel evolutionary history. Mol Biol Evol 32: $2433-2440$ 
Honey JG, Harrison JA, Prothero DR, Stevens MS (1998) Camelidae. In: Janis CM, Scott KM, Jacobs LL (eds.) Evolution of Tertiary Mammals of North America. Volume 1. Terrestrial Carnivores, Ungulates, and Ungulatelike Mammals. Cambridge University Press, Cambridge, pp 439-462

Hooijer DA (1961) Middle Pleistocene mammals from Latamne, Orontes valley, Syria. Ann archéol Syrie 11: 117-132

Howell FC, Fichter LS, Wolf R (1969) Fossil camels in the Omo beds, southern Ethiopia. Nature 223: 150-152

Khaveson IaI (1954) Camels from the Tertiary of the Oriental hemisphere (genus Paracamelus). Trudy paleontol Inst 47: 100-162 [in Russian]

Khaveson IaI (1950) Camels of the genus Paracamelus. Dokl Akad Nauk SSSR 70: 917-920 [in Russian]

Khomenko IP (1912) Camelus bessarabiensis und andere fossile Formen Süd-Bessarabiens. Travaux de la Société des Naturalistes et des Amateurs des Sciences naturelles de Bessarabie, 3: 92127 [Russian and German]Kostopoulos DS, Sen S (1999) Late Pliocene (Villafranchian) mammals from Sarikol Tepe, Ankara, Turkey. Mitt Bayer Staatssamml Paläontol hist Geol 39: 165-202

Kozhamkulova BS (1986) The late Cenozoic two-humped (bactrian) camels of Asia. Quartärpaläontol 6: 93-97

Leidy J (1886) Mastodon and llama from Florida. Proc Acad nat Sci Philadelphia 1886: 11-12

Likius A, Brunet M, Geraads D, Vignaud P (2003) Le plus vieux Camelidae (Mammalia, Artiodactyla) d'Afrique: limite Mio-Pliocène, Tchad. Bull Soc géol Fr 174: 187-193

Linnæus C (1758) Systema naturæ per regna tria naturæ, secundum classes, ordines, genera, species, cum characteribus, differentiis, synonymis, locis. Tomus I. Editio decima, reformata. Salvii, Stockholm, 824 pp.

Logvynenko VM (2000) Camels (Camelidae, Tylopoda) from the Pliocene and Pleistocene of 
Logvynenko V (2001) Paracamelus minor (Camelidae, Tylopoda) - a new camelid species from the middle Pliocene of Ukraine. Vestn zool 35: 39-42

Martini P, Geraads D (2018) Camelus thomasi (Mammalia, Camelidae) from the type-locality Tighennif, Algeria. Geodiversitas 40: 115-134

Martini P, Costeur L, Le Tensorer J-M, Schmid P (2015) Pleistocene camelids from the Syrian desert: the diversity in El Kowm. Anthropologie 119: 687-693

Martini P, Schmid P, Costeur L (2017) Comparative morphometry of the bactrian camel and dromedary. J Mammal Evol 25: 407-425

Marshall CR (2008) A simple method for bracketing absolute divergence times on molecular phylogenies using multiple fossil calibration points. Am Nat 171: 726-742.

Matthew WD, Cook HJ (1909) A Pliocene fauna from western Nebraska. Bull Am Mus Nat Hist 50: $59-210$

Morales J (1984) Venta del Moro: su macrofauna de mamíferos, y bioestratigrafía continental del Mioceno terminal Mediterraneo. PhD thesis, Universidad Complutense de Madrid

Morales J, Soria D, Aguirre E (1980) Camélido finimioceno en Venta del Moro, primera cita para Europa Occidental. Estud geol 36: 139-142

Nanda AC (1978) Occurrence of Camelus sivalensis Falconer and Cautley from the Tatrot Formation of Ambala, India. J Geol Soc India 19: 160-164

Nehring A (1901) Herr A. Nehring gab eine vorläufige Mittheilung über einen fossilen KamelSchädel (Camelus knoblochi) von Sarepta an der Wolga. Sitz-Ber Gesell naturforsch Freunde Berlin 5: 137-144

Orlov YA (1927) Über die Reste eines fossilen Kamels aus dem Gouvernement Akmolinsk (WestSibirien). Ežegod zool muž 28: 496-538

Orlov YA (1929) Über die Reste der fossilen Cameliden aus dem Gouv. Akmolinsk (Westsibirien). Ežegod zool muž 30: 549-587 
631 Patnaik R (2013) Indian Neogene Siwalik mammalian biostratigraphy. An overview. In: Wang X, Flynn LJ, Fortelius M (eds) Fossil Mammals of Asia: Neogene Biostratigraphy and Chronology. Columbia University Press, New York, pp 423-444

Pavlow M (1904) Procamelus du gouvernement de Kherson. Mém Soc Nat nouv Russie 25: 113133

Pickford M, Morales J, Soria D (1995) Fossil camels from the upper Miocene of Europe: implications for biogeography and faunal change. Geobios 28: 641-650 l'Algérie, Alger, 50 pp.

Przewalski NM 1878 From Kul’dzha through Tyan’-Shan’ to Lob-Nor. St Petersburg, 1878 [in Russian.]

Rădulescu C, Burlacu D (1993) On the presence of Paracamelus alutensis (Gr. Ştefănescu) (Camelidae, Mammalia) at Frăteşti (Giurgiu Dept., Romania). An Univ Bucureşti Geol 42:

Rowan J, Locke EM, Robinson JR, Campisano CJ, Wynn JG, Reed KE (2016) Fossil Giraffidae 65-68

Robinson JR, Rowan J, Campisano CJ, Wynn JG, Reed KE (2017) Late Pliocene environmental change during the transition from Australopithecus to Homo. Nature Ecol Evol 1(159) doi:10.1038/s41559-017-0159 (Mammalia, Artiodactyla) from Lee Adoyta, Ledi-Geraru, and late Pliocene dietary evolution 
warm-period deposits in the high arctic yield insight into camel evolution. Nature Comm 4(1550). doi:10.1038/ncomms2516

Sahni MR, Khan E (1988) Pleistocene Vertebrate Fossils and Prehistory of India. Books and Books, New Dehli, 80 pp

Schlosser M (1903) Die fossilen Säugethiere Chinas. Abh k bayer Akad Wiss Math-Phys Kl 22, 1220

Sen S (2010) Camels do not occur in the late Miocene mammal locality of Çobanpinar, Turkey. Russ 664 J Theriol 9: 87-91

Simionescu I (1930) Les vertébrés pliocènes de Măluşteni (Roumanie). Publ Fond Vasile Adamachi 9: 1-69

Simionescu I (1932) Tertiäre und pleistozäne Camelidae in Rumänien. Bull Sect sci Acad roum 15: 1-8

Ştefãnescu G (1895) Le chameau fossile de Roumanie. Anu Mus Geol Paleontol 1894: 91-123

Ştefănescu G (1910) Le chameau fossile de Roumanie est l'ancêtre des chameaux dromadaire et du chameau sauvage d'Afrique. Anu Mus Geol Paleontol 4: 48-69

Steiger C (1990) Vergleichend morphologische Untersuchungen an Einzelknochen des postkranialen Skeletts der Altweltkamele. PhD thesis, Tierärztlichen Ludwig-Maximilians Universität, München

Strauss D, Sadler PM (1989) Classical confidence intervals and Bayesian probability estimates for ends of local taxon ranges. Math Geol 21: 411-427.

Stromer E (1902) Wirbeltierreste aus dem mittleren Pliocän des Natrontales und einige subfossile und recente Säugetierreste aus Aegypten. Z dtsch geol Ges 54: 108-115

Svistun VI (1971) New findings of camel (Tylopoda, Camelidae) remains in Pontian deposits of the South of the USSR European part. Vestn zool 1: 64-68 [in Russian]

Swofford DL (2003) PAUP* Phylogenetic Analysis Using Parsimony (*and other methods). Sinauer Associates, Sunderland. Version 4.01 (build 163) 
Teilhard de Chardin P, Piveteau J (1930) Les mammifères fossiles de Nihowan, Chine. Ann Paléontol 19: 1-134

Teilhard de Chardin P, Trassaert M (1937) The Pliocene Camelidae, Giraffidae, and Cervidae of south-eastern Shansi. Palaeontol Sin C 1 (102): 1-68

Titov VV (2003) Paracamelus from the late Pliocene of the Black Sea region. In: Petculescu A, Ştiucă E (eds) Advances in Vertebrate Paleontology 'Hen to Panta'. Emil Racoviţă Institute of speleology, Bucharest, pp 17-24

Titov VV (2008) Habitat conditions for Camelus knoblochi and factors in its extinction. Quaternary Internatl 179: 120-125

Titov VV, Logvynenko V (2006) Early Paracamelus (Mammalia, Tylopoda) in Eastern Europe. Acta zool cracov 49A: 163-178

Topachevskiy VA (1956) Remains of small camel (Paracamelus alutensis) from the upper Pliocene deposits of the south of Ukraine. Akad Nauk Ukr RSR, Tr Inst Zool 13: 93-100 [in Ukrainian]

Van der Made J, Morales J (1999) Family Camelidae. In: Rössner GE, Heissig K (eds) The Miocene Land Mammals of Europe. Pfeil, München, pp 221-224

Van der Made J, Morales J (2013) Camelids do not occur in the late Miocene mammal locality of Çoban Pinar, Turkey - omissions and contradictions. Russ J Theriol 12: 39-40

Van der Made J, Morales J, Sen S, Aslan F (2002) The first camel from the upper Miocene of Turkey and the dispersal of the camels into the Old World. C R Palevol 1: 117-122

World Association of Veterinary Anatomists (1973) Nomina Anatomica Veterinaria, second ed, A Holzhausen's successors, Vienna, 218 pp

Wu H, Guang X, Al-Fageeh MB, Cao J, Pan S, Zhou H, Zhang L, Abutarboush MH, Xing Y, Xie Z, Alshanqeeti AS, Zhang Y, Yao Q, Al-Shomrani BM, Zhang D, Li J, Manee MM, Yang Z, Yang L, Liu Y, Zhang J, Altammami MA, Wang S, Yu L, Zhang W, Liu S, Ba L, Liu C, Yang X, Meng F, Wang S, Li L, Li E, Li X, Wu K, Zhang S, Wang J, Yin Y, Yang H, Al- 

environments. Nature comm 5 (5188): 1-9

711 Zdansky O (1926) Paracamelus gigas Schlosser. Palaeontol Sin C2 (4): 1-44 712 


\section{Figure captions}

Figure 1. Main elements of NME-MLP-1346. A: braincase in occipital view; B: braincase in left lateral view; C: braincase in dorsal view; D: left zygomatic arch; E: left upper tooth row with P3M3, occlusal view; F: same specimen, buccal view. Scale bar, $20 \mathrm{~cm}$ for Figs A-C, $10 \mathrm{~cm}$ for Figs D-F. See also Supplementary Information 4.

Figure 2. Schematic reconstruction of NME-MLP-1346. Distortion of the temporal and orbital areas prevents accurate reconstruction.

Figure 3. Camelus grattardi from Mille-Logya. A: upper left molar NME-MLP-2665. B: incomplete upper right molar NME-MLP-2684. C: distal right tibia NME-MLP-2584. D: left astragalus NMEMLP-1189. Scale bar, 5 cm for Figs A-B, 10 cm for Figs C-D.

Figure 4. Camelidae from the Omo Shungura Formation; A-C: Camelus grattardi; D-E: ?Camelus sp. A: left mandible with m1, m2, incomplete m3, and roots of p4, NME-L480-7, oblique view. B: proximal (posterior ?) phalanx NME-Omo 119-68-14, plantar view. C: right lower molar (probably m2), collected by C. Arambourg, occlusal view. D: right mandible with m3, NME-Omo 28-67-494, occlusal view. E: proximal (anterior ?) phalanx NME-Omo-28-67-577, palmar view. Scale bar, 10 $\mathrm{cm}$.

Figure 5. One of the most parsimonious trees obtained by TNT and PAUP. $\mathrm{L}=48$; $\mathrm{ci}=60$; $\mathrm{ri}=64$. C. = Camelus; M. = Megacamelus P. = Paracamelus. Extant taxa are in bold. Support values are given as bootstrap / Bremer (decay) index values. Unambiguous synapomorphies are: Node 6: length c-m1 / length $\mathrm{m} 1-\mathrm{m} 3(0 \rightarrow 1)$. Node $5: \mathrm{p} 3$ present $(0 \rightarrow 1)$; P3 relative to $\mathrm{P} 4(0 \rightarrow 1)$. Node 4 : paraglenoid tubercle $(0 \rightarrow 1)$; WP4 / WM1 $(0 \rightarrow 1)$. Node 3 : mandibular thickening $(0 \rightarrow 1)$; scars on proximal phalanges $(0 \rightarrow 1)$. Node 2 : ramus ascendens $(0 \rightarrow 1)$; WP4 / WM1 $(1 \rightarrow 2)$; molar 
739 length/breadth $(0 \rightarrow 1)$; upper molar styles $(0 \rightarrow 1)$. Node 1 : choanae $(0 \rightarrow 1)$. Paracamelus alutensis:

740 size $(1 \rightarrow 0)$; mandibular thickening $(0 \rightarrow 1)$. $P$. gigas: size $(1 \rightarrow 2)$; squamosal reaches orbital level

$741(0 \rightarrow 1)$; metapodials relative to femur $(2 \rightarrow 1)$. C. thomasi: mandibular thickening $(1 \rightarrow 2) ; \mathrm{p} 4$

742 molarization $(1 \rightarrow 2)$. C. bactrianus: metapodials relative to femur $(0 \rightarrow 1)$. C. dromedarius:

743 infraorbital shelf $(1 \rightarrow 0)$; mandibular thickening $(1 \rightarrow 0)$; 44 molarization $(1 \rightarrow 0)$; astragalus cuboid

744 facet $(0 \rightarrow 2)$. C. knoblochi: size $(1 \rightarrow 2)$; infraorbital shelf $(1 \rightarrow 2)$; p4 molarization $(1 \rightarrow 2)$.

745

746 Table captions

747 Table 1. Dental measurements of NME-MLP-1346 ( $\mathrm{L}=$ length; $\mathrm{W}=$ width).

748

749 Table 2. Tooth height in some Camelus; height of unworn molars cannot be measured in most

750 specimens, because their base is concealed in bone. Height of unworn teeth is underlined. 


\section{SUPPLEMENTARY INFORMATION 2}

Character description (their numbers follow those of the data matrix (at the end of this files in TNT format; also in Nexus format as Supplementary Information 4); those that were regarded as too variable, too ambiguous to be used, or autapomorphic, are listed separately and identified by letters. Figures are not to scale; see also figures of the main text for $C$. grattardi.)

0) overall size is rather homogeneous but Megacamelus, P. gigas, and C. knoblochi are larger, whereas P. alutensis is smaller.

1) the choanae are V-shaped in most species, but those of $C$. dromedarius are usually more Ushaped (Martini et al. 2017); unexpectedly, those of the Razdorskaya skull of C. knoblochi (Titov 2008, fig.2) are rather U-shaped.

2) The ventral orbital margin is narrow in C. dromedarius and C. thomasi, but forms a variably deep shelf in other species.

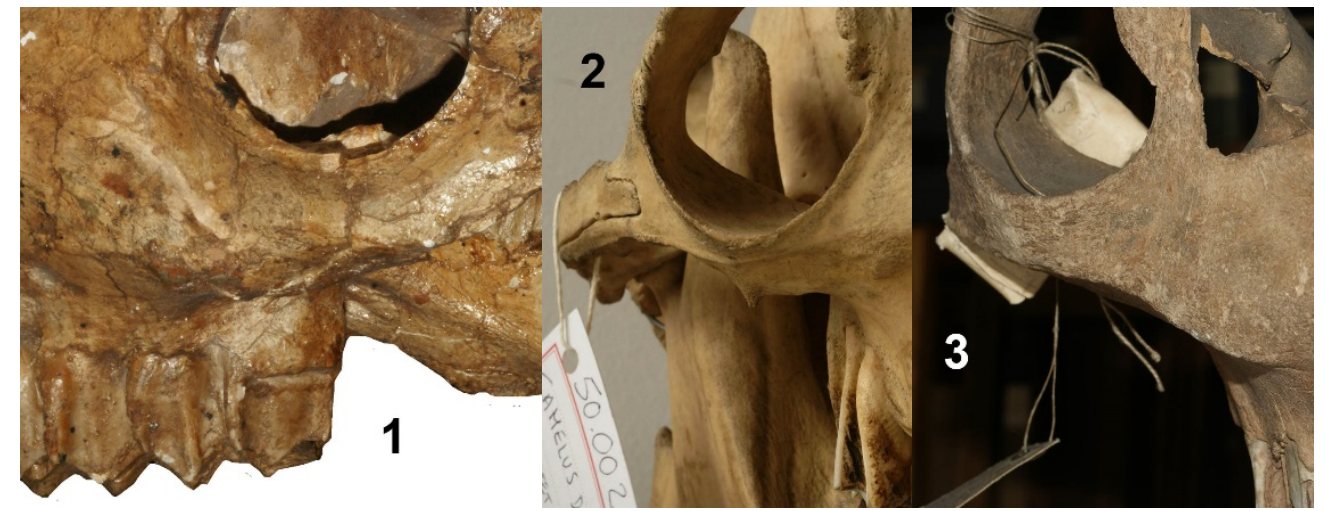

Character 2, ventral orbital margin. 1) Megacamelus merriami (AMNH FM23201), broad; 2) Camelus dromedarius (CCEC 5000-2069), narrow; 3) Camelus knoblochi (ZIN 8678), broad

3) the squamosal tongue on the zygomatic arch reaches the level of the orbit in C. grattardi (Fig. 1 of the main text) and P. alexejevi (Khaveson 1954, fig. 1), and comes close to it in M. merriami, but is distinctly behind it in other species (not scored in C. sivalensis because, although several specimens preserve this area, the sutures are not clearly identifiable). 


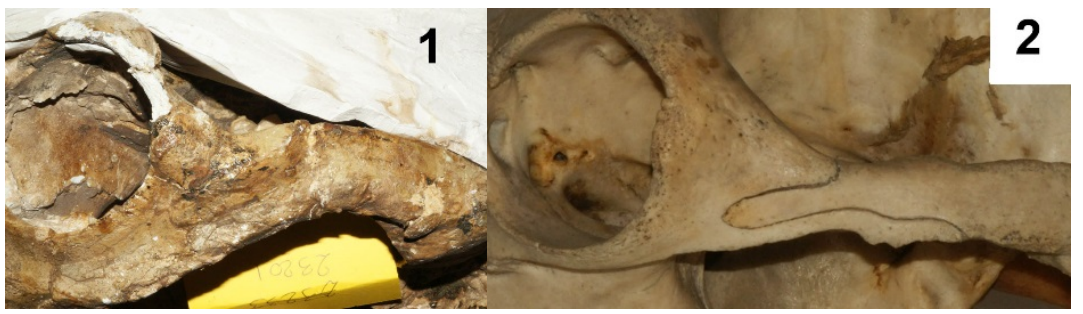

Character 3, anterior extent of the squamosal tongue 1) Megacamelus merriami (AMNH FM23201), almost reaching orbital level 2) modern Camelus, behind it.

4) The supra-orbital foramina are close to each other in modern Camelus and M. merriami, but wider apart in C. sivalensis and C. grattardi; the condition is unknown in Paracamelus.

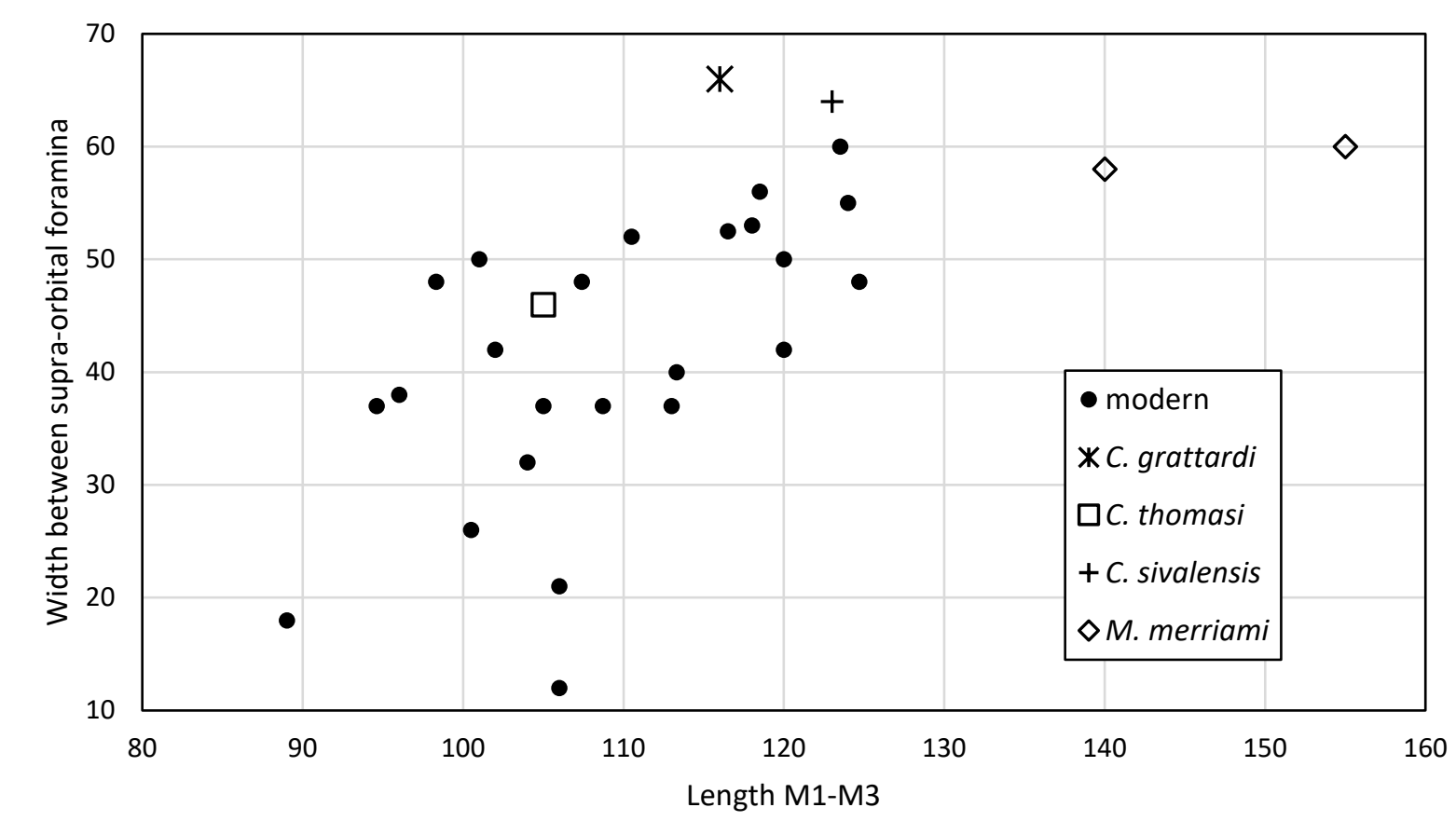

Character 4, distance between the supra-orbital foramina (raw data in Supplementary Information 3)

5) the paraglenoid tubercle, lateral to the glenoid fossa, is present in most Camelus but absent in C. grattardi, American forms, and at most weak in Paracamelus (Zdansky 1926:5 'Der dieselbe bei rezenten Kamelen aussen begrenzende Vorsprung ist kaum vorhanden.'; Khaveson 1954, fig. 1)

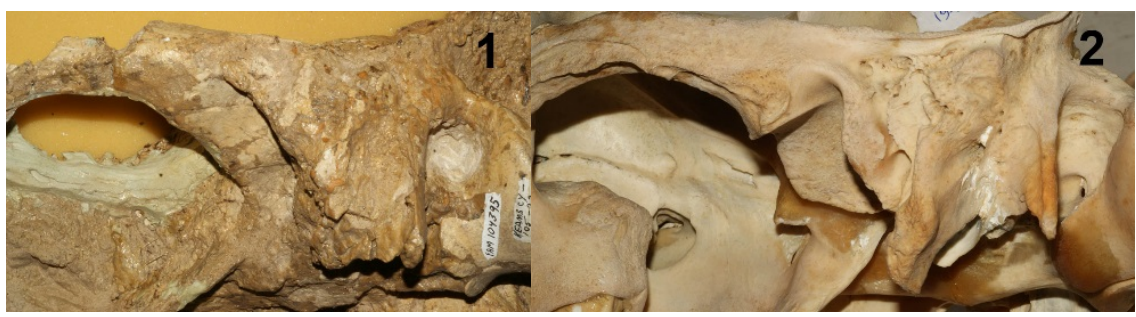

Character 5, paraglenoid tubercle. 1) Megacamelus merriami (AMNH FM104395), absent; 2) Camelus bactrianus (MNHN ZM.1970-44), present. 
6) the length of the muzzle can be estimated by the length between the lower canine and $m 1$ (thus obviating for the rare preservation of the incisors and the irregular presence of p3). This measurement separates Paracamelus, in which it is distinctly greater than the length $\mathrm{m} 1-\mathrm{m} 3$, from Camelus and N. American forms, in which it is at most slightly longer. The shortness of the muzzle in C. grattardi is inferred from the juvenile specimen KNM-WT-39366, from just below the Lokalalei tuff at c. $2.55 \mathrm{Ma}$, in which it is as short as in modern Camelus of similar ontogenic age. The incomplete mandible KNM-ER-2608 probably had a longer pre-dental portion, but could belong to Paracamelus instead. No measurement can be taken on C. thomasi, but MNHN TER1685 unambiguously shows that the muzzle was short.

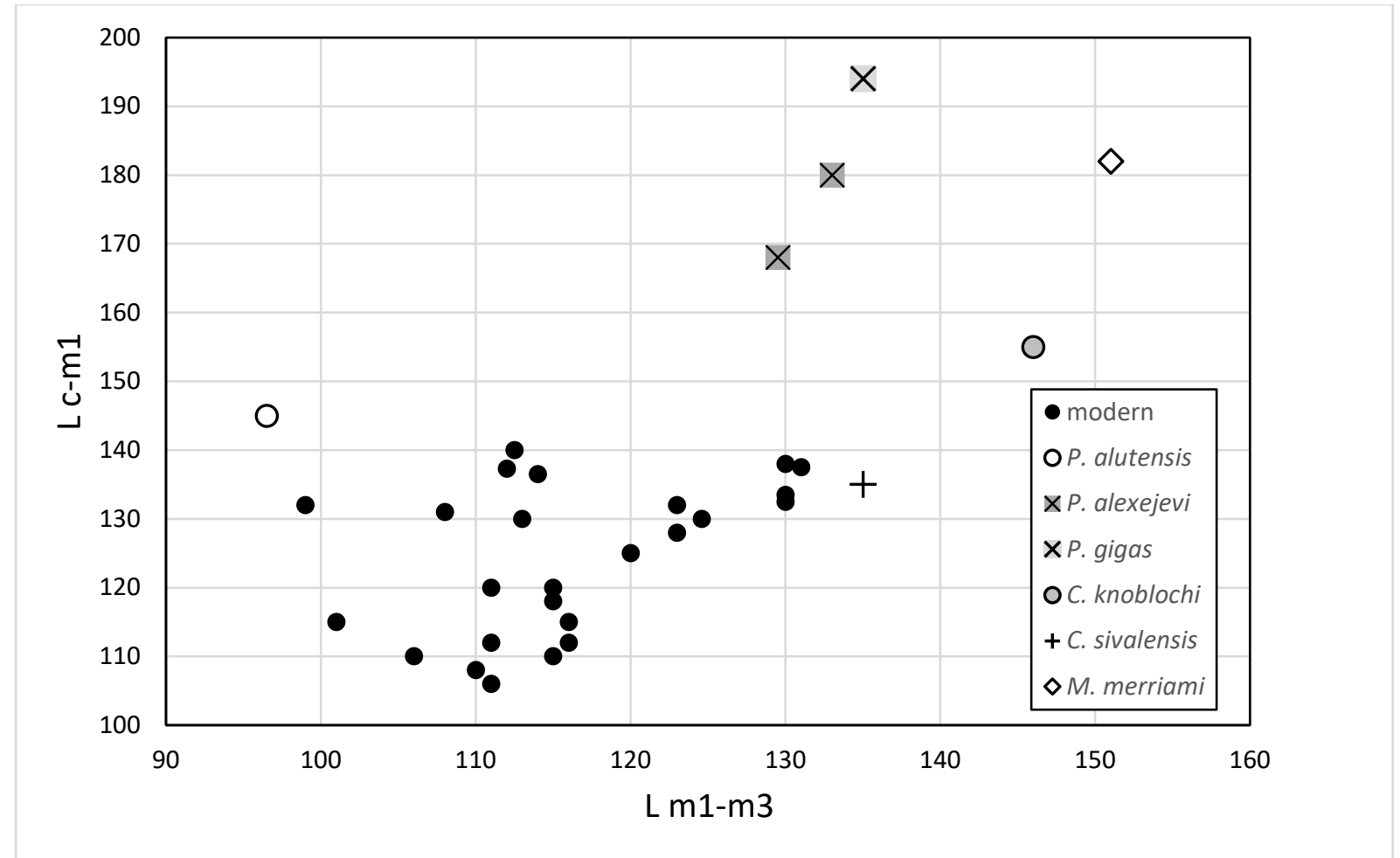

Character 6, relative length of the predental portion of the muzzle, a proxy for the length of the muzzle. The smallest modern Camelus is a very old specimen, in which wear has reduced molar length (raw data in Supplementary Information 3).

7) the ascending ramus of the mandible displays significant differences, with limited intra-specific variation (in Camelus, the shape of the coronoid process is a good distinguishing feature at species level [Martini et al. 2017; Martini \& Geraads 2018]). The anterior border of the ramus is usually oblique, but vertical or even slightly inclined forwards in younger forms, but also in M. merriami. 


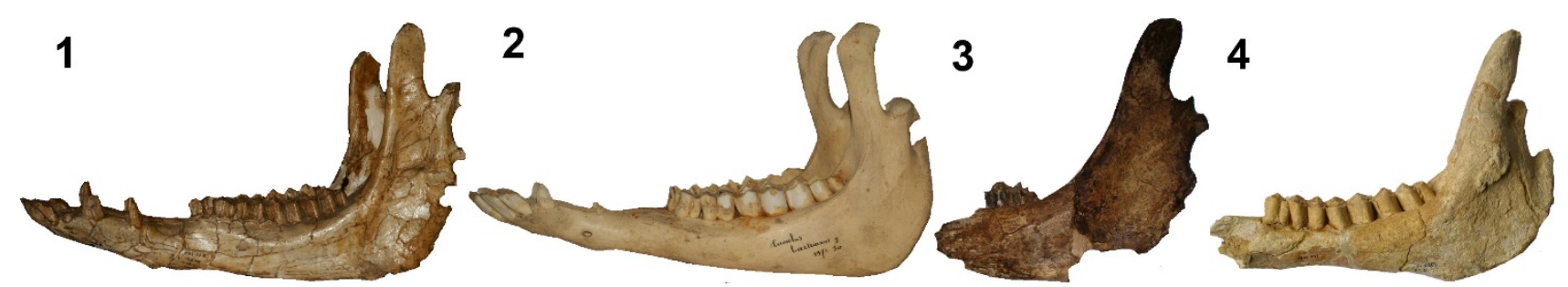

Character 7, anterior border of the ascending ramus. 1) Megacamelus merriami (AMNH FM23216), vertical; 2) modern Camelus, vertical; 3) Camelus grattardi (KNM-WT 16454), oblique; 4) Camelus thomasi, oblique.

8) all camels have a robust mandibular corpus; although there is much intra-specific variation, this is especially marked in C. bactrianus, C. knoblochi, and P. alutensis, and still more so in C. thomasi, whose pachyostosis is highly characteristic.

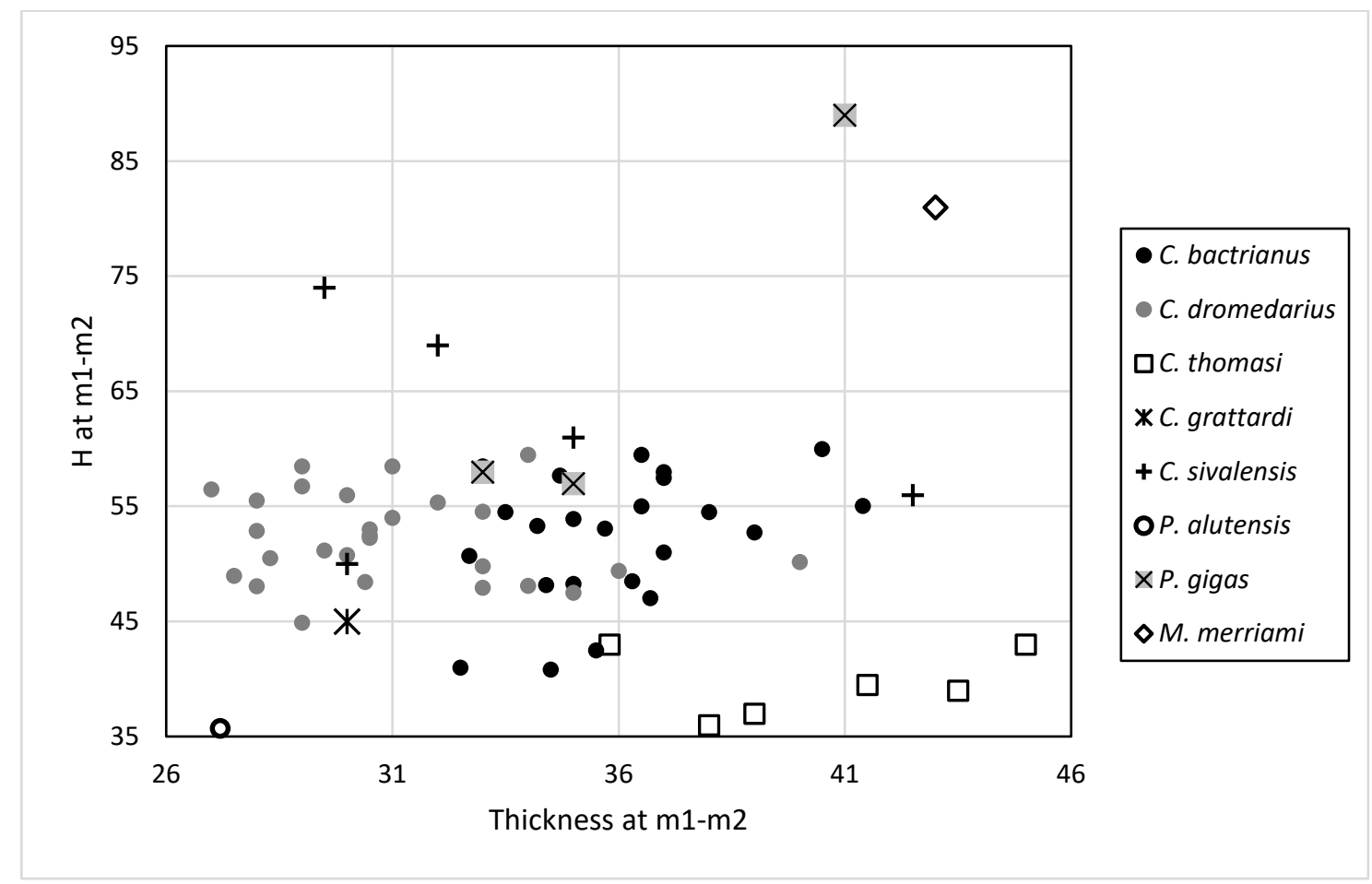

Character 8, plot of mandibular corpus depth vs. thickness between $\mathrm{m} 1$ and $\mathrm{m} 2$ (raw data in Supplementary Information 3).

9) The loss of p3 is the best diagnostic character of Camelus, unambiguously distinguishing it from Paracamelus in the Old World. The earliest precisely dated fossil lacking this tooth is the mandible NME-L480-7 from Omo Shungura G3 at c. 2.2 Ma.

10) a shortening of P3 is probably functionally correlated with the loss of p3.

11, 12) It seems that this loss of $\mathrm{p} 3$ is associated with a trend towards a greater molarisation of P3 and p4, through the development of a lingual wall. The lingual crescent of P3 is complete in all 
known specimens of C. sivalensis (NHMUK-M 15347, AMNH-FM19832, Gaur et al., 1984, fig.2) and C. thomasi (Martini \& Geraads 2018). The p4 is variable in C. sivalensis and C. bactrianus, but on the average it is more molarized in the latter species than in C. dromedarius. The $\mathrm{p} 4$ has a clear lingual wall in the single available specimens of $C$. thomasi and C. knoblochi.

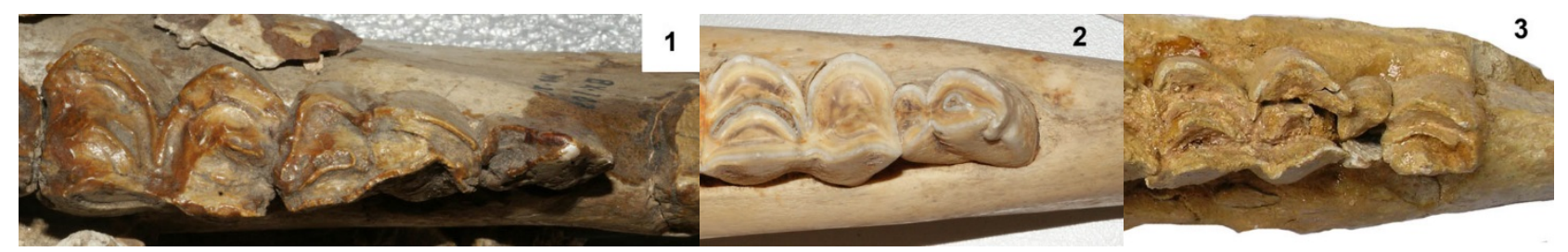

Character 12, molarisation of p4: 1) Megacamelus merriami (AMNH F23216), not molarized; 2) Camelus bactrianus (MNHN.ZM.1971-50), molarized; 3) Camelus thomasi (MNHN TER-1685), molarized.

$13,14)$ in younger species of Camelus, the molars are narrower at their base, both relative to the width of P4, and relative to their length, than in early forms.

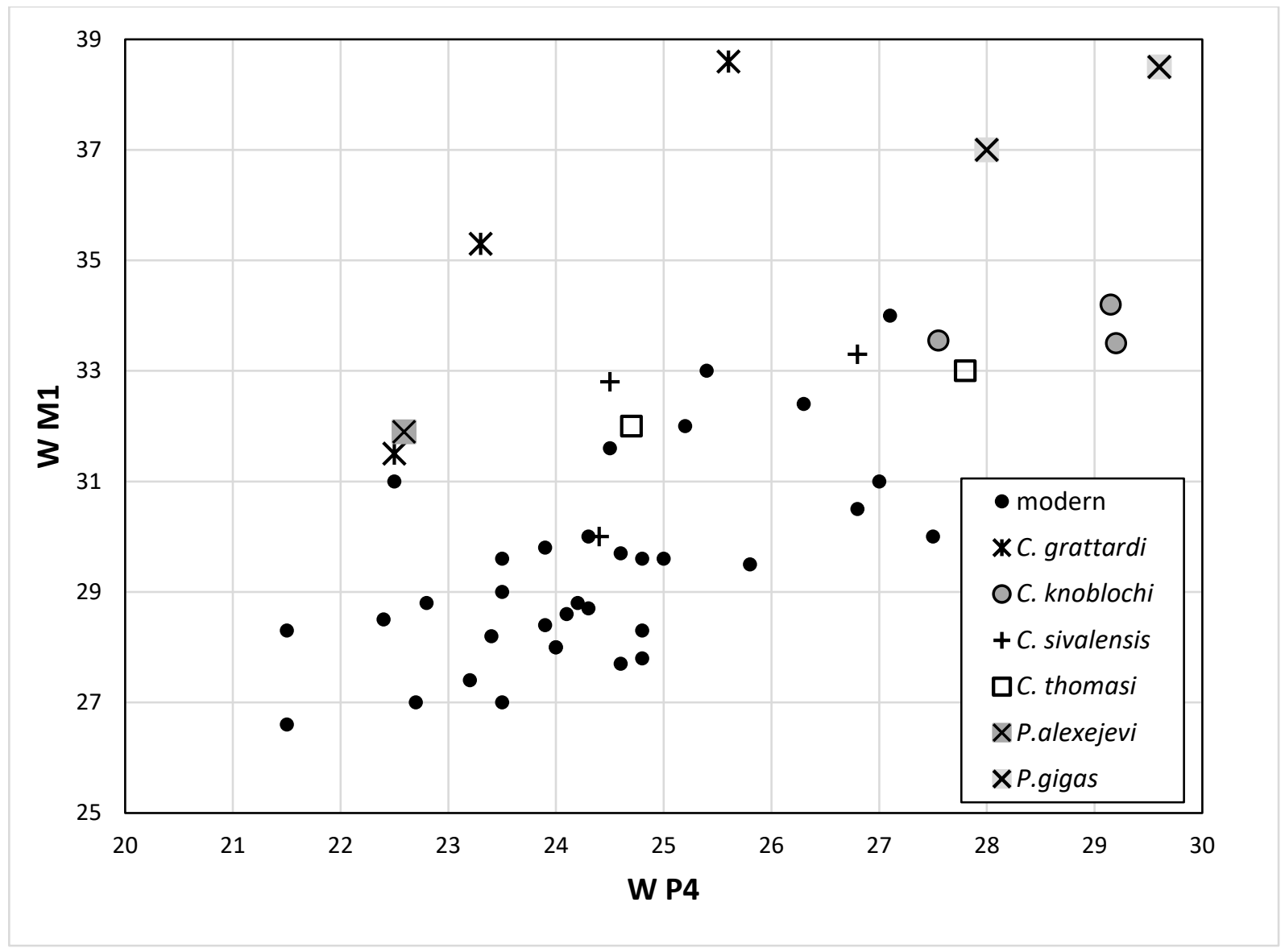

Character 13, relative widths of P4 and M1 (raw data in Supplementary Information 3). 


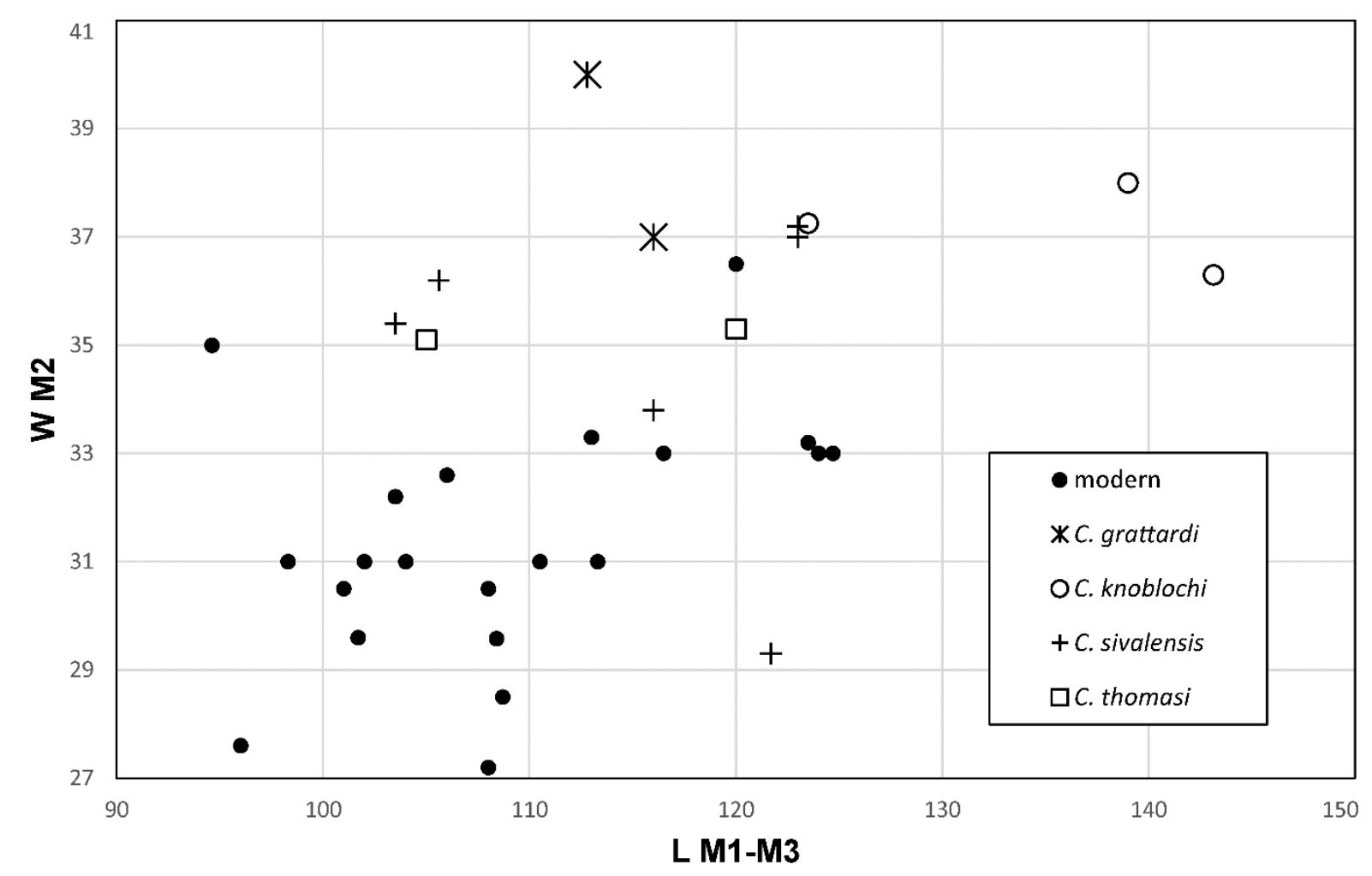

Character 14, width of M2 relative to length of M1-M3 (raw data in Supplementary Information 3).

15) upper molars ribs (labial central pillars on the paracone and metacone) are weak in most Camelus, but they are better marked in C. sivalensis, in P. alexejevi, in a number of isolated finds possibly attributable to Paracamelus (Orlov 1929, pl.42, fig.3; van der Made \& Morales 1999, fig. 22.1; Rybczynski et al. 2013, fig.3c), and in the N. American M. merriami and Aepycamelus major (but they are distinctly weaker in Megatylopus).

16) upper molar styles are usually more reduced in younger species of Camelus, although there is significant variation, especially with wear.

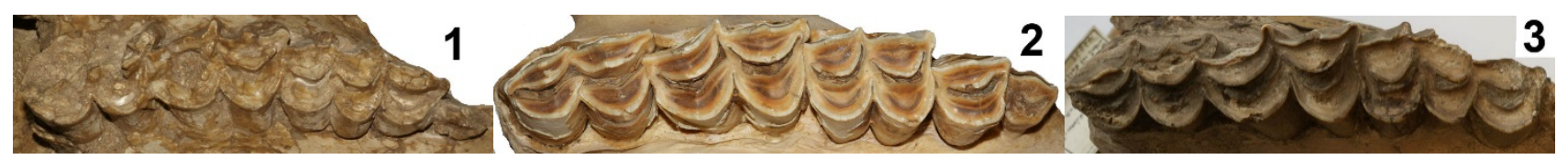

Characters 15-16, upper molar ribs and styles. 1) Megacamelus merriami (AMNH F23202), strong; 2) Camelus bactrianus (MNHN 1970-44), weak; 3) Camelus sivalensis (NHMUK PV OR 3664), strong.

17) Geraads (2014) showed that the distal articulation of the humerus of C. grattardi, like that of other early forms, is more nearly perpendicular to the long axis of the bone than that of modern ones. 
18) the astragalus provides several distinctive criteria, but most of them display high intra-specific variation. The lateral lip of the proximal trochlea extends farther towards the plantar side in the dromedary than in the Bactrian camel, and only C. thomasi is similar to the latter.
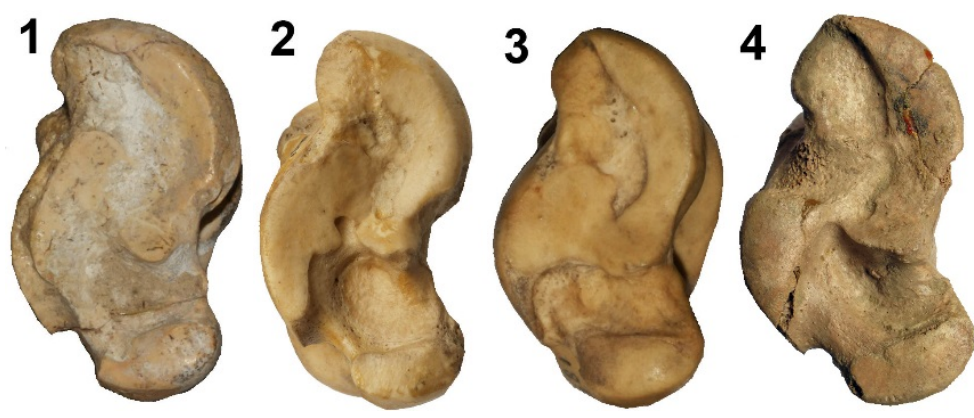

Character 18, plantar extent of the lateral tibial lip. 1) Megacamelus merriami (AMNH FM104232), long; 2) Camelus dromedarius, long 3) Camelus bactrianus, short; 4) Camelus thomasi (MNHN TER-1656), short.

19) in C. dromedarius, the cuboid facet is relatively wider than in C. bactrianus (Steiger 1990; Martini et al. 2017); there is much variation in other taxa, but P. gigas (Zdansky 1926, pl. 4, fig. 11) and P. alexejevi (Khaveson 1954, pl. 7, fig. 5) are similar to the dromedary.

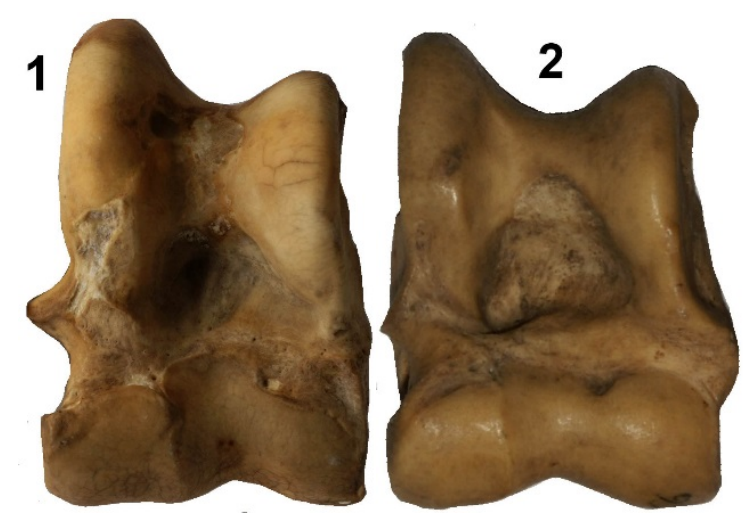

Character 19, width of the cuboid facet 1) Camelus dromedarius, broad 2) Camelus bactrianus, narrow

20) on the palmar/plantar side of the proximal phalanges, the ligament scars of the proximal end extend farther distally in geologically younger species than in earlier forms, including P. aguirrei from Venta del Moro (van der Made \& Morales 1999, fig. 22.3), and the Plio-Pleistocene Yukon camel (Rybczynski et al. 2013); however, according to Zdansky (1926), P. gigas has long scars.

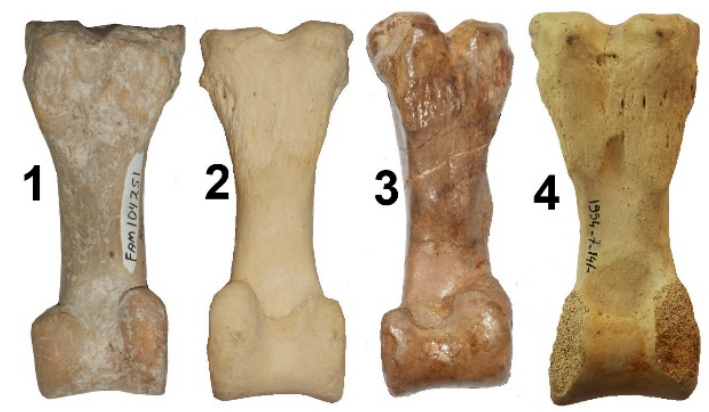


Character 20, length of the ligament scars on the proximal phalanges. 1) Megacamelus merriami (AMNH FM104251), short; 2) modern Camelus, long; 3) C. sivalensis (AMNH FM19832), short; 4) C. thomasi (MNHN TER-1674), long.

21) Khaveson (1954) observed that the distal part of the limbs in $P$. alexejevi is relatively longer than in modern forms. Camelus sivalensis and M. merriami also have long metapodials, while P. gigas, instead, is more similar to C. dromedarius in this regard, C. bactrianus being the most different in its short metapodials.

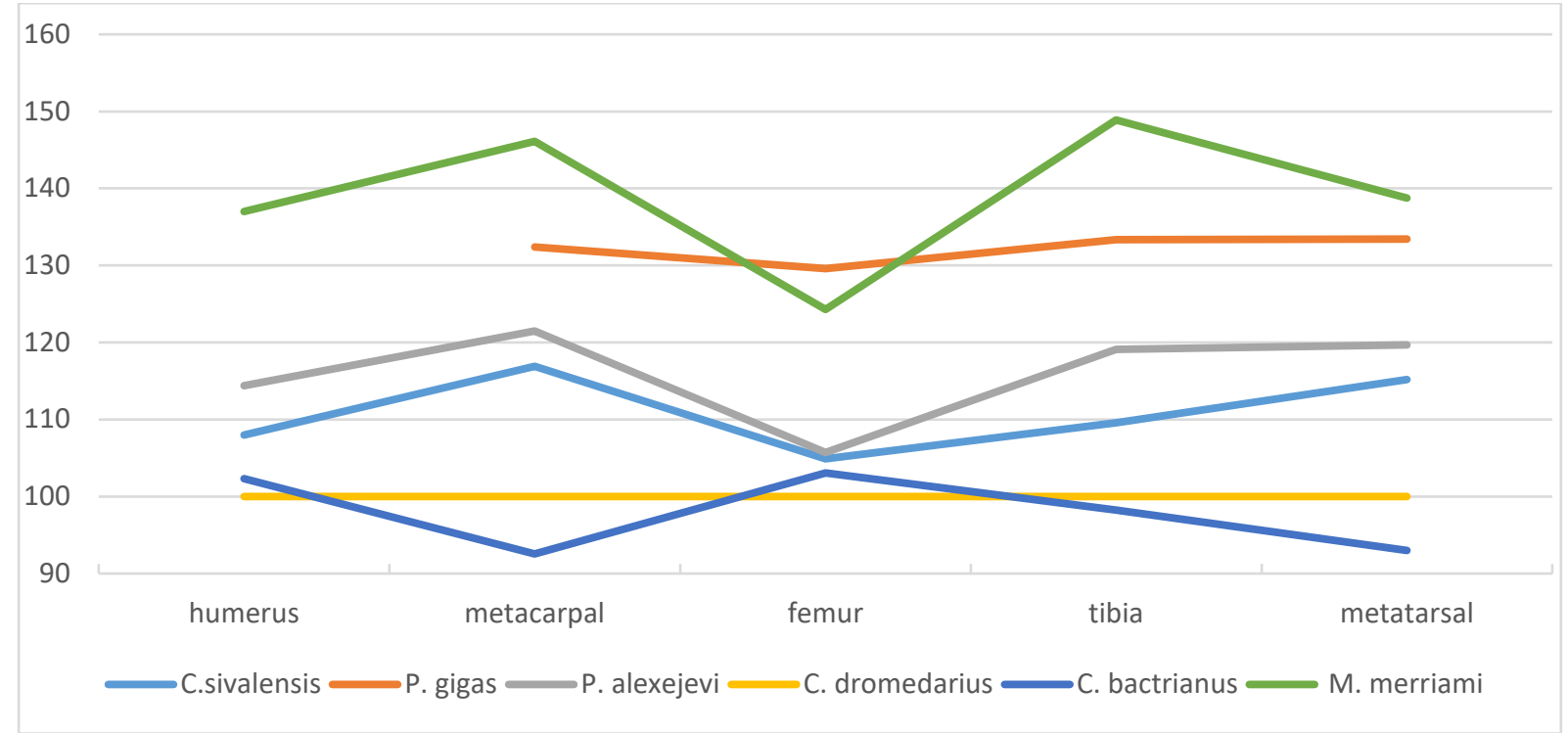

Character 21. Relative length of some long bones (Camelus dromedarius $=100$ ). The metatarsal is short relative to the femur in C. bactrianus, moderately long in C. dromedarius and P. gigas, and long in M. merriami, $P$. alexejevi, and C. sivalensis.

\section{Characters not used:}

A) Cranial proportions are hard to evaluate, because most fossil crania are distorted and/or largely reconstructed. Camelus crania are clearly broader over the orbits than the well-preserved cranium of Megatylopus AMNH-FM14071, but probably not broader than those of the distorted crania of Megacamelus.

B) As observed by Zdansky (1926), it is only in Megatylopus (AMNH-FM14071) that the lachrymal bone reaches the lachrymal vacuity, which is much larger than in the other taxa. C) A possible synapomophy of modern Camelus is the early fusion of facial sutures; by contrast, they are still clearly visible in adults of Megacamelus merriami. However, the condition in many fossil species is too uncertain for a reliable use of this feature.

D) The skull of Camelus sivalensis AMNH-FM19832 is unique in having a I3 located far from the canine but the variability of this feature and the condition in most fossil species are unknown. 
E) The position of the orbit relative to the tooth-row is very variable in modern forms, and no fossil specimen is outside this variation. Khaveson (1954) stated that it is more posterior in P. alexejevi, but this is based upon a largely reconstructed cranium.

F) the proportions of the occiput display much intra-specific variations, but it does look less broad in C. grattardi than in other taxa. If so, the condition in this species is autapomorphic.

G) Khaveson largely based his new subgenus Neoparacamelus, based upon P. alutensis, on the absence on goat folds in lower molars, but this is hard to understand, because a goat fold is clearly present on the $\mathrm{m} 3$ of the type specimen (cast in UCBL). The goat fold is frequent in Camelidae but is never strongly expressed.

H) C. grattardi is clearly less hypsodont than other Camelus (the original material of C. thomasi includes an unworn M3, and several specimens of $C$. sivalensis preserve exposed unworn molars), but the degree of hypsodonty is often hard to evaluate with precision, because the base of unworn molars is still embedded in bone. In addition, the slight hypsodonty of the outgroup M. merriami is obviously a derived feature, and its use would invert the polarity.

I) In the astragalus, the size of the lateral spine is a good distinguishing feature between living species, but is too variable to be reliably used in fossils.

J) the lateral and plantar calcanear facets are usually contiguous in modern C. bactrianus and in C. thomasi, but never (5 specimens) in M. merriami; they are also separate in NME-MLP-1189, but there is too much intra-specific variation for this character to be used.

K) the proximolateral calcanear facet reaches distally the distolateral facet in M. merriami, but not in Old World camels. However the proximolateral facet is short in South-American Camelidae, suggesting that the contact in M. merriami is merely an effect of its large size.

L) The unfused part of the metapodials is on the average longer in specimens assigned to Paracamelus (P. gigas: Zdansky 1926, pl. 2, fig. 10 and pl. 4, fig.15; Teilhard de Chardin \& Trassaert 1937, pl. 1, fig. 4; P. alexejevi: Baigusheva 1971, pl. 6, fig. 2; Svistun 1971, fig. 1; Titov \& Logvynenko, 2006, fig. 5c) than in Camelus, but there is much variability in species of both genera (P. gigas: Zdansky 1926, pl. 2, fig. 13; P. alexejevi: Khaveson 1954, pl. 6; an early Pliocene metatarsal from Chad assigned to P. gigas [Likius et al. 2003, fig. 3] has a short unfused part). 


\section{Matrix and character list, in TNT format:}

xread

'Camelidae'

2210

M_merriami 2020100100000000001002

C_grattardi 1?2000000110?0010? 110 ?

C_dromedarius $\quad 1101110101100211111211$

C_bactrianus 1011110111101211110010

C_sivalensis 101 ? 010001111100001002

C_knoblochi 212111011110221111 ? 0??

C_thomasi 10111100211121010 ? 001 ?

P_gigas 2011 ? 01000000 ? 000 ? 1211

P_alexejevi 1? 10 ? 010000 ? 000000 ? 2? 2

P_alutensis 0 ? ? ? ? 10100 ? 0 ? ? 0 ? 0 ? ? ?

;

ccode $+[0.21$

;

cnames

$\{0$ size small medium large ;

$\{1$ choanae V-shaped U-shaped ;

\{ 2 infra-orbital_shelf narrow moderate broad ;

\{ 3 squamosal_reaches_orbital_level yes no ;

\{ 4 supra-orbital_foramina wide_apart close ;

\{ 5 paraglenoid_tubercle at_most_weak distinct ;

\{ 6 length_c-m1/length_m1-m3 short long ;

\{ 7 ramus_ascendens oblique vertical ;

\{ 8 mandibular_thickening no slight strong;

\{ 9 p3_present absent ;

\{ 10 P3_relative_to_P4 large small ;

\{ 11 P3_internal_crescent incomplete complete ;

\{ 12 p4_molarisation no variable yes ;

\{ 13 WP4/WM1 narrow intermediate broad ;

$\{14$ molar_breadth/length broad narrow ;

\{ 15 upper_molars_ribs moderate weak ;

\{ 16 upper_molars_styles strong weak ;

\{ 17 distal_humerus transverse oblique ;

\{ 18 astragalus_lateral_lip short long ;

\{ 19 astragalus_cuboid_facet narrow variable broad ;

\{ 20 scars_on_proximal_phalanges short long ;

\{ 21 metapodials_relative_to_femur short intermediate long ; 


\begin{tabular}{|c|c|c|c|c|}
\hline number & origin & taxon & W M2 & L M1-M3 \\
\hline & & & modern & modern \\
\hline 1951-102 & MNHN & C. bactrianus & $\begin{array}{r}33,3 \\
\end{array}$ & 101 \\
\hline 1896-2017 & MNHN & C. bactrianus & 33 & 113 \\
\hline no \# 2 & MNHN & C. bactrianus & 36,5 & 124 \\
\hline $1974-60$ & MNHN & C. bactrianus & 31,9 & 105 \\
\hline 1991-695 & MNHN & C. bactrianus & 33 & 118,5 \\
\hline 1962-183 & MNHN & C. bactrianus & 33,2 & 116,5 \\
\hline $1970-44$ & MNHN & C. bactrianus & 31 & 123,5 \\
\hline 1985-243 & MNHN & C. bactrianus & 32,8 & 110,5 \\
\hline $1972-35$ & MNHN & C. bactrianus & 31,5 & 118 \\
\hline $1985-1900$ & MNHN & C. dromedarius & 30,5 & 100,5 \\
\hline 2007-1438 & MNHN & C. dromedarius & 28 & 108 \\
\hline 1991-302 & MNHN & C. dromedarius & 31 & 107,4 \\
\hline 1931-101 & MNHN & C. dromedarius & 32,6 & 104 \\
\hline $1929-46$ & MNHN & C. dromedarius & 28,5 & 106 \\
\hline $1912-442$ & MNHN & C. dromedarius & 27,6 & 108,7 \\
\hline 1934-59 & MNHN & C. dromedarius & 31 & 96 \\
\hline 1912-151 & MNHN & C. dromedarius & 31 & 98,3 \\
\hline 2007-1432 & MNHN & C. dromedarius & 31 & 102 \\
\hline 1985-202 & MNHN & C. dromedarius & 33 & 113,3 \\
\hline 1964-213 & MNHN & C. dromedarius & 35 & 124,7 \\
\hline $1865-1$ & MNHN & C. dromedarius & 30,8 & 94,6 \\
\hline $1852-564$ & MNHN & C. dromedarius & 31 & 108,7 \\
\hline $1897-337$ & MNHN & C. dromedarius & 29,6 & 104 \\
\hline 5000-2064 & MNHN & C. dromedarius & 32,2 & 106,3 \\
\hline $5000-2065$ & MNHN & C. dromedarius & 29,58 & 103,5 \\
\hline 5000-2068 & MNHN & C. dromedarius & 27,2 & 111,5 \\
\hline \multirow[t]{2}{*}{$5000-2069$} & MNHN & C. dromedarius & 30,5 & 108 \\
\hline & & & C. grattardi & C. grattardi \\
\hline Omo75s-70-956 & NME & C. grattardi & 40 & $\begin{array}{r}112,8 \\
\end{array}$ \\
\hline \multirow[t]{2}{*}{ MLP-1346 } & NME & C. grattardi & 37 & 116 \\
\hline & & & C. thomasi & C. thomasi \\
\hline TER 1816 & MNHN & C. thomasi & \begin{tabular}{r|}
35,1 \\
\end{tabular} & $\begin{array}{r}105 \\
\end{array}$ \\
\hline \multirow[t]{2}{*}{ TER 1689} & MNHN & C. thomasi & $\begin{array}{r}35,3 \\
\end{array}$ & $\begin{array}{r}120 \\
\end{array}$ \\
\hline & & & C. knoblochi & C. knoblochi \\
\hline ZIN 8678 & Titov, 2008 & C. knoblochi & 38 & $\begin{array}{r}139 \\
\end{array}$ \\
\hline ROMK & Titov, 2008 & C. knoblochi & 37,25 & 123,5 \\
\hline \multirow[t]{2}{*}{ VSEGEI } & Titov, 2008 & C. knoblochi & $\begin{array}{r}36,3 \\
\end{array}$ & 143,15 \\
\hline & & & C. sivalensis & C. sivalensis \\
\hline 36664 & NHMUK & C. sivalensis & $\begin{array}{r}37 \\
\end{array}$ & $\begin{array}{r}123 \\
\end{array}$ \\
\hline 15347 & NHMUK & C. sivalensis & 35,4 & 103,5 \\
\hline 16405 & NHMUK & C. sivalensis & 33,8 & 116 \\
\hline PUA Rh 23/83 & & C. sivalensis & 29,3 & 121,7 \\
\hline FM19832 & AMNH & C. sivalensis & 36,2 & 105,6 \\
\hline FM19785 & AMNH & C. sivalensis & 37,2 & 123 \\
\hline
\end{tabular}




\begin{tabular}{|c|c|c|c|}
\hline number & origin & taxon & $\begin{array}{l}\text { Height of the } \\
\text { medial side }\end{array}$ \\
\hline & & & C. grattardi \\
\hline \multirow[t]{2}{*}{ MLP-1189 } & NME & C. grattardi & 79 \\
\hline & & & C. sivalensis \\
\hline NHMUK42564 & NHMUK & C. sivalensis & 75 \\
\hline NHMUK40593 & NHMUK & C. sivalensis & 63 \\
\hline \multirow[t]{2}{*}{ NHMUK40597 } & NHMUK & C. sivalensis & 81,7 \\
\hline & & & C. thomasi \\
\hline MNHN-TER-1669 & MNHN & C. thomasi & 79 \\
\hline \multirow[t]{4}{*}{ MNHN-TER-1670 } & MNHN & C. thomasi & 75 \\
\hline & & & $P$. gigas \\
\hline & Zdansky, 1926 & P. gigas & 88,5 \\
\hline & & & M. merriami \\
\hline FM104232 & AMNH & M. merriami & 82,7 \\
\hline FM104231 & AMNH & M. merriami & 89,5 \\
\hline FM104236 & AMNH & M. merriami & 81,8 \\
\hline FM104234 & AMNH & M. merriami & 83 \\
\hline \multirow[t]{2}{*}{ FM104230 } & AMNH & M. merriami & 88,5 \\
\hline & & & C. bactrianus \\
\hline $1851-466$ & MNHN & C. bactrianus & 65,7 \\
\hline $1898-239$ & MNHN & C. bactrianus & 71,5 \\
\hline 1926-151 & MNHN & C. bactrianus & 70 \\
\hline $1971-50$ & MNHN & C. bactrianus & 71,3 \\
\hline $1972-35$ & MNHN & C. bactrianus & 67,7 \\
\hline MHNG ARCO 826.20-1501.1 & Martini et al., 2017 & C. bactrianus & 64,75 \\
\hline NMB 2430 & Martini et al., 2017 & C. bactrianus & 68 \\
\hline MHNG MAMO 1168.053 & Martini et al., 2017 & C. bactrianus & 71 \\
\hline NMB 10390 & Martini et al., 2017 & C. bactrianus & 70,75 \\
\hline NMB 5918 & Martini et al., 2017 & C. bactrianus & 66 \\
\hline NMBE 1023261 & Martini et al., 2017 & C. bactrianus & 64 \\
\hline ZM 20382 & Martini et al., 2017 & C. bactrianus & 69 \\
\hline MSNM Ma 6415 & Martini et al., 2017 & C. bactrianus & 67,5 \\
\hline MHNG MAMO 1063.089 & Martini et al., 2017 & C. bactrianus & 76,75 \\
\hline MHNG MAMO 810.035 & Martini et al., 2017 & C. bactrianus & 72 \\
\hline MHNG ARCO 826.20-1501.2 & Martini et al., 2017 & C. bactrianus & 71,5 \\
\hline \multirow[t]{2}{*}{ NBM 10902} & Martini et al., 2017 & C. bactrianus & 68 \\
\hline & & & C. dromedarius \\
\hline $1892-15$ & MNHN & C. dromedarius & 76 \\
\hline $1876-259$ & MNHN & C. dromedarius & 61,8 \\
\hline $1884-2210$ & MNHN & C. dromedarius & 70 \\
\hline $1895-387$ & MNHN & C. dromedarius & 63 \\
\hline $1899-96$ & MNHN & C. dromedarius & 71,2 \\
\hline $2007-1435$ & MNHN & C. dromedarius & 69,8 \\
\hline $1925-205$ & MNHN & C. dromedarius & 67 \\
\hline Ek2 & Martini et al., 2017 & C. dromedarius & 63,5 \\
\hline Ek3 & Martini et al., 2017 & C. dromedarius & 68 \\
\hline MHNG MAMO 78.028 & Martini et al., 2017 & C. dromedarius & 62,5 \\
\hline ZM 13130 & Martini et al., 2017 & C. dromedarius & 65 \\
\hline Ek5 & Martini et al., 2017 & C. dromedarius & 71 \\
\hline MHNG ARCO 826.20-1502.6 & Martini et al., 2017 & C. dromedarius & 66,5 \\
\hline MHNG ARCO 826.20-1502.4 & Martini et al., 2017 & C. dromedarius & 67,5 \\
\hline NMBE 1023266 & Martini et al., 2017 & C. dromedarius & 65,5 \\
\hline
\end{tabular}




\begin{tabular}{|c|}
\hline Distal breadth \\
\hline C. grattardi \\
\hline 51,5 \\
\hline C. sivalensis \\
\hline 53,4 \\
\hline 46 \\
\hline 59,6 \\
\hline C. thomasi \\
\hline 59,5 \\
\hline 54,5 \\
\hline P. gigas \\
\hline 62 \\
\hline M. merriami \\
\hline 67 \\
\hline 63 \\
\hline 63 \\
\hline 60 \\
\hline 65 \\
\hline C. bactrianus \\
\hline 48,3 \\
\hline 50 \\
\hline 53,5 \\
\hline 48,6 \\
\hline 53,7 \\
\hline 47 \\
\hline 51 \\
\hline 50 \\
\hline 50,5 \\
\hline 47 \\
\hline 49 \\
\hline 47,5 \\
\hline 46,5 \\
\hline 57,5 \\
\hline 49,5 \\
\hline 51 \\
\hline 51 \\
\hline C. dromedarius \\
\hline 55 \\
\hline 45,5 \\
\hline 52,5 \\
\hline 47,5 \\
\hline 52,5 \\
\hline 51 \\
\hline 52,5 \\
\hline 44 \\
\hline 50 \\
\hline 45 \\
\hline 50 \\
\hline 54 \\
\hline 48 \\
\hline 48 \\
\hline 51,5 \\
\hline
\end{tabular}




\begin{tabular}{|c|c|c|c|c|}
\hline number & origin & taxon & L M1-M3 & $\begin{array}{l}\text { W between } \\
\text { sup-orb. } \\
\text { Foramina }\end{array}$ \\
\hline & & & C. bactrianus & C. bactrianus \\
\hline 1951-102 & MNHN & C. bactrianus & 101 & 50 \\
\hline 1896-2017 & MNHN & C. bactrianus & 113 & 37 \\
\hline no \# 2 & MNHN & C. bactrianus & 124 & 55 \\
\hline $1971-50$ & MNHN & C. bactrianus & 120 & 50 \\
\hline $1974-60$ & MNHN & C. bactrianus & 105 & 37 \\
\hline 1991-695 & MNHN & C. bactrianus & 118,5 & 56 \\
\hline $1962-183$ & MNHN & C. bactrianus & 116,5 & 52,5 \\
\hline $1970-44$ & MNHN & C. bactrianus & 123,5 & 60 \\
\hline $1985-243$ & MNHN & C. bactrianus & 110,5 & 52 \\
\hline \multirow[t]{2}{*}{$1972-35$} & MNHN & C. bactrianus & 118 & 53 \\
\hline & & & C. dromedarius & C. dromedarius \\
\hline $1985-1900$ & MNHN & C. dromedarius & $\begin{array}{r}100,5 \\
\end{array}$ & 26 \\
\hline $2007-1437$ & MNHN & C. dromedarius & 89 & 18 \\
\hline 1991-302 & MNHN & C. dromedarius & 107,4 & 48 \\
\hline $1912-150$ & MNHN & C. dromedarius & 106 & 12 \\
\hline $1929-46$ & MNHN & C. dromedarius & 106 & 21 \\
\hline $1912-442$ & MNHN & C. dromedarius & $\mid 108,7$ & 37 \\
\hline \begin{tabular}{|l|}
$1934-59$ \\
\end{tabular} & MNHN & C. dromedarius & 96 & 38 \\
\hline $1912-151$ & MNHN & C. dromedarius & 98,3 & 48 \\
\hline $2007-1432$ & MNHN & \begin{tabular}{|l|} 
C. dromedarius \\
\end{tabular} & 102 & 42 \\
\hline \begin{tabular}{|l|}
$1985-202$ \\
\end{tabular} & MNHN & C. dromedarius & 113,3 & 40 \\
\hline \begin{tabular}{|l|}
$1964-213$ \\
\end{tabular} & MNHN & C. dromedarius & 124,7 & 48 \\
\hline $1865-1$ & MNHN & C. dromedarius & 94,6 & 37 \\
\hline \begin{tabular}{|l|}
$1897-337$ \\
\end{tabular} & MNHN & C. dromedarius & 104 & 32 \\
\hline $5000-2063$ & CCEC & C. dromedarius & 106,5 & 45 \\
\hline $5000-2064$ & CCEC & C. dromedarius & 106,3 & 38,5 \\
\hline $5000-2065$ & CCEC & C. dromedarius & 103,5 & 33 \\
\hline $5000-2066$ & CCEC & C. dromedarius & 108,4 & 31,5 \\
\hline $5000-2067$ & CCEC & C. dromedarius & 111,5 & 27,3 \\
\hline $5000-2068$ & CCEC & C. dromedarius & 111,5 & 21,5 \\
\hline $5000-2069$ & CCEC & C. dromedarius & 108 & 36,5 \\
\hline \multirow[t]{2}{*}{\begin{tabular}{|l|}
$1908-101$ \\
\end{tabular}} & MNHN & hybrid & 120 & 42 \\
\hline & & & C. grattardi & C. grattardi \\
\hline \multirow[t]{2}{*}{ MLP-1346 } & NME & C. grattardi & 116 & 66 \\
\hline & & & C. thomasi & C. thomasi \\
\hline \multirow[t]{2}{*}{ TER 1816} & MNHN & C. thomasi & 105 & 46 \\
\hline & & & C. sivalensis & C. sivalensis \\
\hline \multirow[t]{2}{*}{36664} & NHMUK & C. sivalensis & 123 & 64 \\
\hline & & & M. merriami & M. merriami \\
\hline 23202 & AMNH & M. merriami & 140 & 58 \\
\hline $23202 A$ & AMNH & M. merriami & 155 & 60 \\
\hline
\end{tabular}




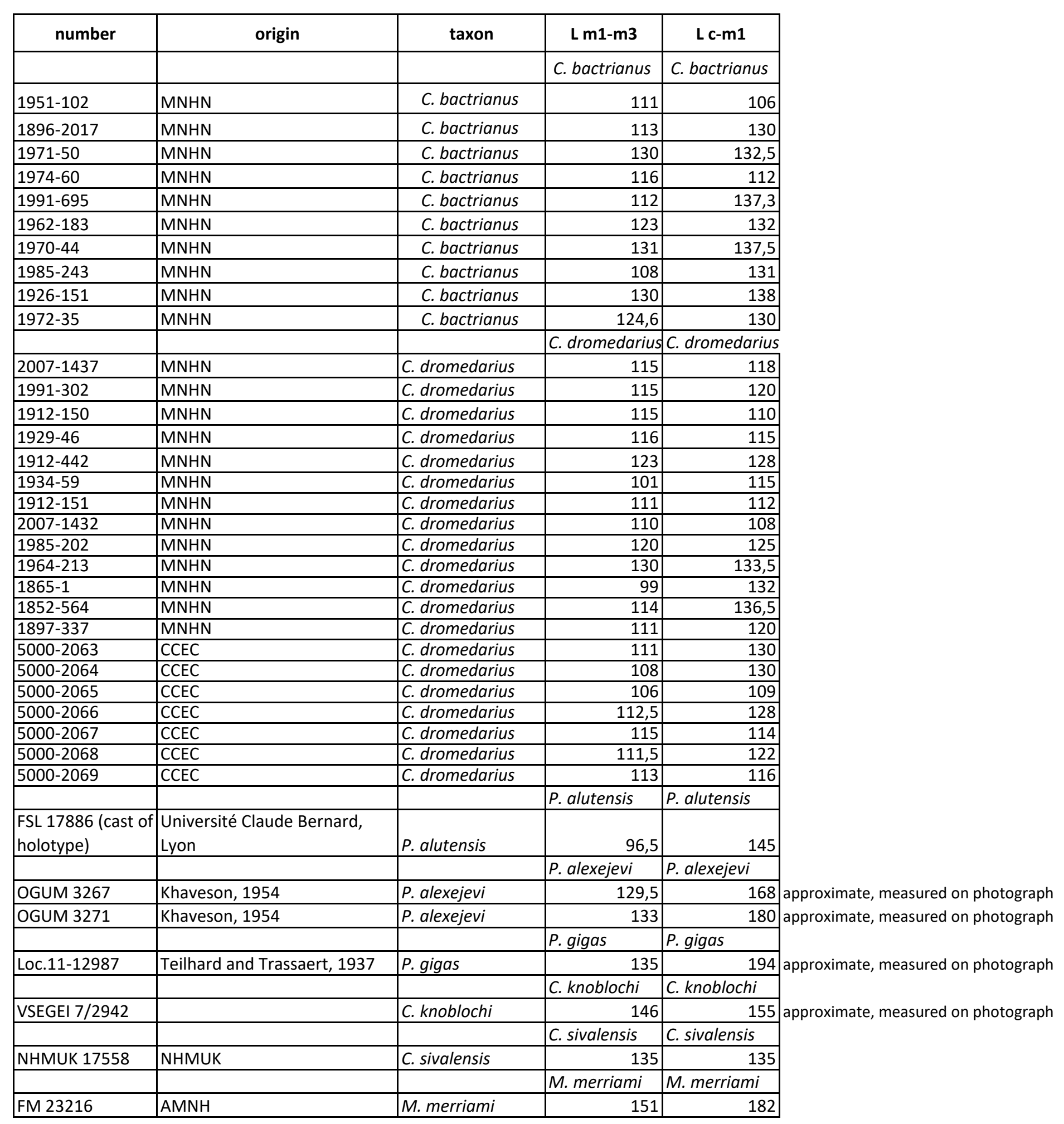




\begin{tabular}{|c|c|c|c|c|}
\hline number & origin & taxon & W P4 & W M1 \\
\hline & & & modern & modern \\
\hline 1896-2017 & MNHN & C. bactrianus & 26,8 & 30,5 \\
\hline no \# 2 & MNHN & C. bactrianus & 27,1 & 34 \\
\hline 1971-50 & MNHN & C. bactrianus & 25,4 & 33 \\
\hline $1974-60$ & MNHN & C. bactrianus & 24,3 & 30 \\
\hline 1991-695 & MNHN & C. bactrianus & 24,8 & 28,3 \\
\hline $1962-183$ & MNHN & C. bactrianus & 24,6 & 29,7 \\
\hline $1970-44$ & MNHN & C. bactrianus & 27 & 31 \\
\hline $1985-243$ & MNHN & C. bactrianus & 24,8 & 29,6 \\
\hline $1972-35$ & MNHN & C. bactrianus & 25,2 & 32 \\
\hline $1876-259$ & MNHN & C. dromedarius & 22,4 & 28,5 \\
\hline $1985-1900$ & MNHN & C. dromedarius & 24,6 & 27,7 \\
\hline $2007-1438$ & MNHN & C. dromedarius & 23,5 & 27 \\
\hline 1991-302 & MNHN & C. dromedarius & 25 & 29,6 \\
\hline \begin{tabular}{|l|}
$1931-101$ \\
\end{tabular} & MNHN & C. dromedarius & 22,8 & 28,8 \\
\hline $1912-150$ & MNHN & C. dromedarius & 21,5 & 26,6 \\
\hline $1929-46$ & MNHN & C. dromedarius & 23,5 & 29 \\
\hline \begin{tabular}{|l|}
$1912-442$ \\
\end{tabular} & MNHN & C. dromedarius & 22,7 & 27 \\
\hline \begin{tabular}{|l|}
$1934-59$ \\
\end{tabular} & MNHN & C. dromedarius & 23,2 & 27,4 \\
\hline \begin{tabular}{|l|}
$1912-151$ \\
\end{tabular} & MNHN & C. dromedarius & 24,1 & 28,6 \\
\hline $2007-1432$ & MNHN & C. dromedarius & 24,3 & 28,7 \\
\hline $1985-202$ & MNHN & C. dromedarius & 27,5 & 30 \\
\hline \begin{tabular}{|l|}
$1964-213$ \\
\end{tabular} & MNHN & C. dromedarius & 26,3 & 32,4 \\
\hline \begin{tabular}{|l|}
$1865-1$ \\
\end{tabular} & MNHN & C. dromedarius & 24,2 & 28,8 \\
\hline \begin{tabular}{|l|}
$1852-564$ \\
\end{tabular} & MNHN & C. dromedarius & 21,5 & 28,3 \\
\hline \begin{tabular}{|l|}
$1897-337$ \\
\end{tabular} & MNHN & C. dromedarius & 24,8 & 27,8 \\
\hline $2007-1435$ & MNHN & C. dromedarius & 23,9 & 28,4 \\
\hline $5000-2064$ & CCEC & C. dromedarius & 24,5 & 31,6 \\
\hline $5000-2065$ & CCEC & C. dromedarius & 23,5 & 29,6 \\
\hline $5000-2066$ & CCEC & C. dromedarius & 23,4 & 28,2 \\
\hline $5000-2067$ & CCEC & C. dromedarius & 25,8 & 29,5 \\
\hline $5000-2068$ & CCEC & C. dromedarius & 23,9 & 29,8 \\
\hline $5000-2069$ & CCEC & C. dromedarius & 24 & 28 \\
\hline $5000-2070$ & CCEC & C. dromedarius & 22,5 & 31 \\
\hline \multirow[t]{2}{*}{$1908-101$} & MNHN & C. dromedarius & 24 & 28 \\
\hline & & & C. grattardi & C. grattardi \\
\hline Omo75s-70-956 & NME & C. grattardi & 25,6 & 38,6 \\
\hline \multirow[t]{2}{*}{ MLP-1346 } & NME & C. grattardi & 23,3 & 35,3 \\
\hline & & & C. thomasi & C. thomasi \\
\hline TER 1816 & MNHN & C. thomasi & 24,7 & 32 \\
\hline TER 1689 & MNHN & C. thomasi & 27,8 & 33 \\
\hline \multirow{3}{*}{ Imean } & & & P. alexejevi & P. alexejevi \\
\hline & Logvynenko, 2000 & P. alexejevi & 22,59 & 31,9 \\
\hline & & & P. gigas & P. gigas \\
\hline \multirow[t]{3}{*}{22192} & Teilhard and Trassaert, 1937 & P. gigas & \begin{tabular}{|r|}
28 \\
\end{tabular} & 37 \\
\hline & Zdansky, 1926 & P. gigas & 29,6 & 38,5 \\
\hline & & & C. knoblochi & C. knoblochi \\
\hline ZIN 8678 & Titov, 2008 & C. knoblochi & 29,2 & 33,5 \\
\hline ROMK & Titov, 2008 & C. knoblochi & 27,55 & 33,55 \\
\hline \multirow[t]{2}{*}{ VSEGEI } & Titov, 2008 & C. knoblochi & 29,15 & 34,2 \\
\hline & & & C. sivalensis & C. sivalensis \\
\hline 36664 & NHMUK & C. sivalensis & 26,8 & 33,3 \\
\hline 15347 & NHMUK & C. sivalensis & 24,5 & 32,8 \\
\hline 16405 & NHMUK & C. sivalensis & 24,4 & 30 \\
\hline PUA Rh 23/83 & Gaur et al., 1984 & C. sivalensis & 19,6 & 28 \\
\hline FM19832 & AMNH & C. sivalensis & 21,3 & 34,2 \\
\hline
\end{tabular}




\begin{tabular}{|c|c|c|c|c|c|}
\hline & \multicolumn{5}{|c|}{ length of long bones } \\
\hline & C. sivalensis & P. gigas & P. alexejevi & C. dromedarius & C. bactrianus \\
\hline reference & $\begin{array}{l}\text { AMNH FM } \\
19832\end{array}$ & $\begin{array}{l}\text { Zdansky, } \\
1926\end{array}$ & $\begin{array}{l}\text { Logvynenko, } \\
\text { 2000; mean }\end{array}$ & $\begin{array}{l}\text { Martini et al., } \\
\text { 2017; mean }\end{array}$ & $\begin{array}{l}\text { Martini et al., } \\
\text { 2017; mean }\end{array}$ \\
\hline humerus & 420 & & 426 & $\begin{array}{r}389 \\
\end{array}$ & $\begin{array}{r}398 \\
\end{array}$ \\
\hline metacarpal & 408 & 462 & 425 & 349 & 323 \\
\hline femur & 514 & 635 & 518 & 490 & 505 \\
\hline tibia & 493 & 600 & 518 & 450 & 442 \\
\hline metatarsal & 410 & 475 & 429 & 356 & 331 \\
\hline
\end{tabular}


P. merriami

Harrison, 1985

533

510

609

670

494 


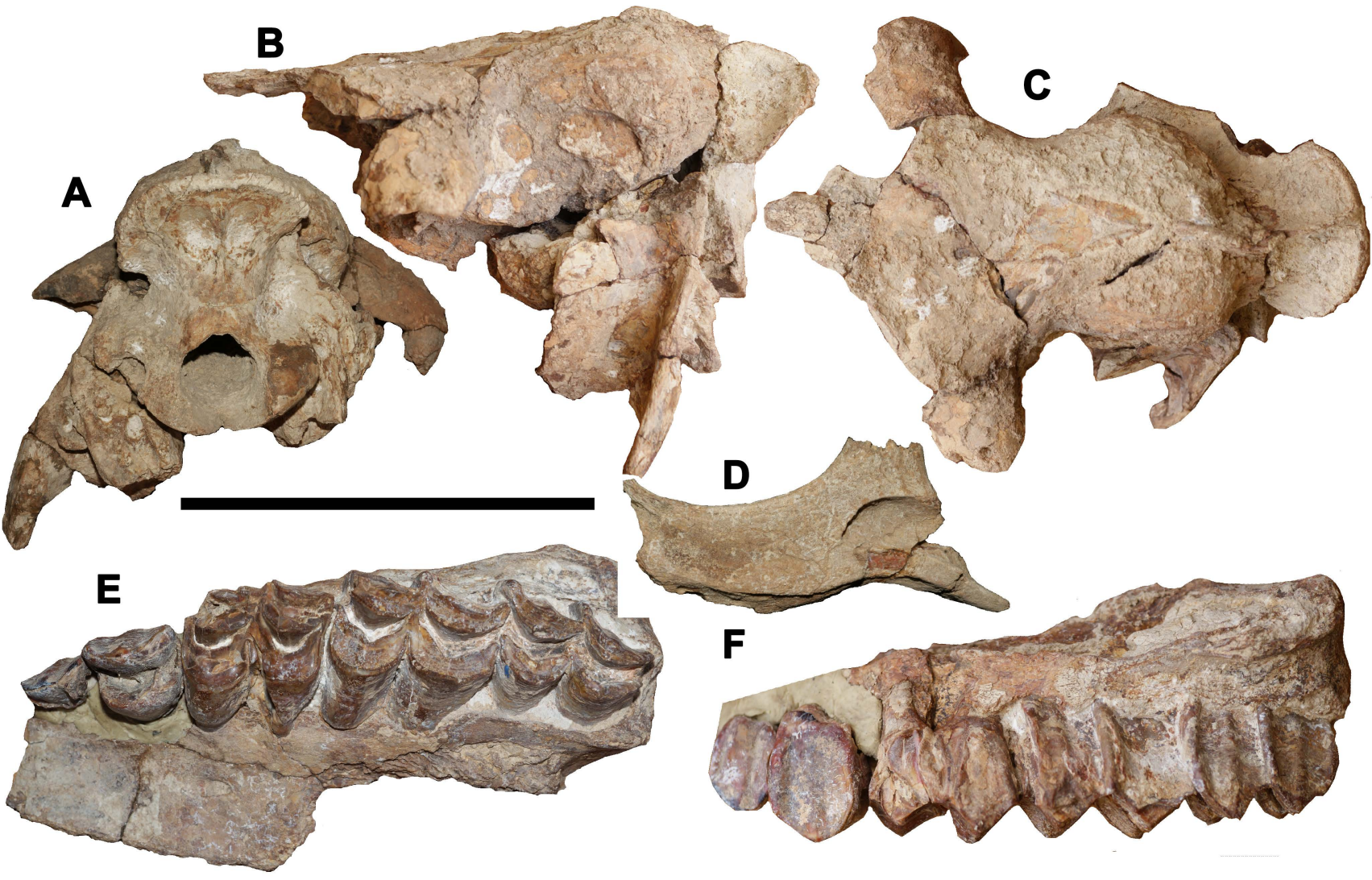



A

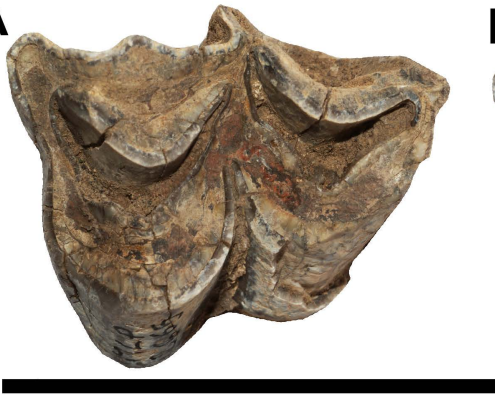

B

(2)

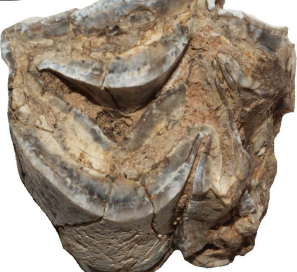

C

$x^{2}$

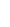
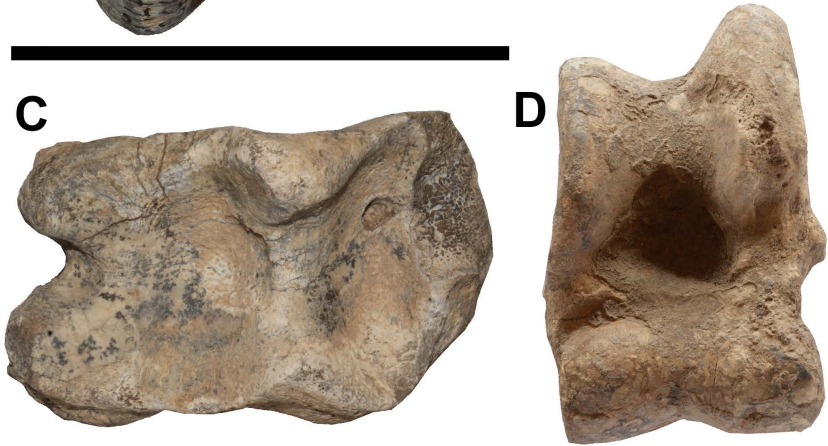
M.merriami

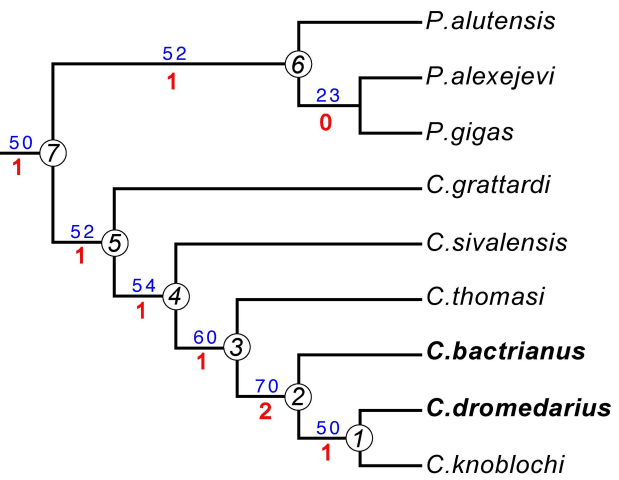


Table 1. Dental measurements of NME-MLP-1346 (L = length; $\mathrm{W}=$ width).

LP3 WP3 LP4 WP4 LM1 WM1 LM2 WM2 LM3 WM3 M1-M3

$\begin{array}{lllllllllll}21 & 15 & 24 & 23 & 37 & 35 & 44 & 37 & 43.2 & 30+ & 116\end{array}$ 
Table 2. Tooth height in some Camelus; height of unworn molars cannot be measured in most specimens, because their base is concealed in bone. Height of unworn teeth is underlined.

\begin{tabular}{lccccccc} 
& \multicolumn{1}{c}{ C. grattardi } & C. dromedarius & \multicolumn{2}{c}{ C. sivalensis } & C. thomasi \\
& NME-MLP-1346 & extant & \multicolumn{2}{c}{ NHMUK } & type \\
Tooth & P3 & P4 & N=3 & 40570 & 40561 & 15357 & \\
Length & 21 & 24 & mean 17.4 & 19.8 & 50.3 & 54.4 & 39 \\
Height & $\underline{24.2}$ & $\underline{33}$ & $26-\underline{30}$ & $28++$ & $\underline{58}$ & $\underline{62}$ & $50+$
\end{tabular}

